WSRC-TR-2003-00530

\title{
ACCOUNTING FOR A VITRIFIED PLUTONIUM WASTE FORM IN THE YUCCA MOUNTAIN REPOSITORY TOTAL SYSTEM PERFORMANCE ASSESSMENT (TSPA)
}

\author{
James Marra, WSRC/SRTC \\ William Ebert, ANL \\ Westinghouse Savannah River Company/Savannah River Technology Center \\ and Argonne National Laboratory \\ Publication Date: December 1, 2003
}

Westinghouse Savannah River Company

Savannah River Site

Aiken, SC 29808

Prepared for the U.S. Department of Energy Under Contract Number DEAC09-96SR18500

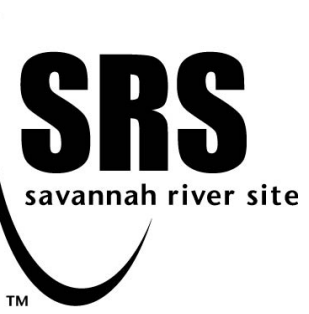


WSRC-TR-2003-00530

\section{DISCLAIMER}

This report was prepared for the United States Department of Energy under Contract No. DEAC09-96SR18500 and is an account of work performed under that contract. Neither the United States Department of Energy, nor WSRC, nor any of their employees makes any warranty, expressed or implied, or assumes any legal liability or responsibility for accuracy, completeness, or usefulness, of any information, apparatus, or product or process disclosed herein or represents that its use will not infringe privately owned rights. Reference herein to any specific commercial product, process, or service by trade name, trademark, name, manufacturer or otherwise does not necessarily constitute or imply endorsement, recommendation, or favoring of same by Westinghouse Savannah River Company or by the United States Government or any agency thereof. The views and opinions of the authors expressed herein do not necessarily state or reflect those of the United States Government or any agency thereof.

Printed in the United States of America

Prepared For

U.S. Department of Energy 
Key Words:

Lanthanide borosilicate (LaBS) glass

Can-in-canister

Glass degradation

Plutonium immobilization

Retention: Permanent

\title{
ACCOUNTING FOR A VITRIFIED PLUTONIUM WASTE FORM IN THE YUCCA MOUNTAIN REPOSITORY TOTAL SYSTEM PERFORMANCE ASSESSMENT (TSPA)
}

\author{
James Marra, WSRC/SRTC \\ William Ebert, ANL \\ Westinghouse Savannah River Company/Savannah River Technology Center \\ and Argonne National Laboratory \\ Publication Date: December 1, 2003
}

Westinghouse Savannah River Company

Savannah River Site

Aiken, SC 29808

Prepared for the U.S. Department of Energy Under Contract Number DE-AC09-96SR18500

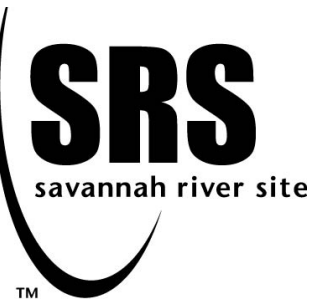


WSRC-TR-2003-00530

\section{REVIEWS AND APPROVALS}

James Marra, Author, SRTC

Date

William Ebert, Author, ANL

Date

Alex Cozzi, Technical Reviewer

Date

E. William Holtzscheiter, Level 3 Manager

Date 


\section{TABLE OF CONTENTS}

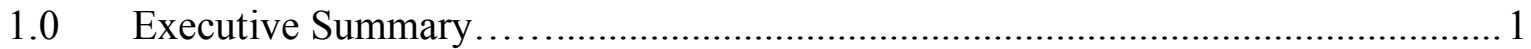

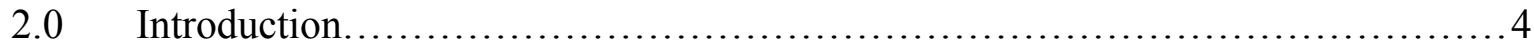

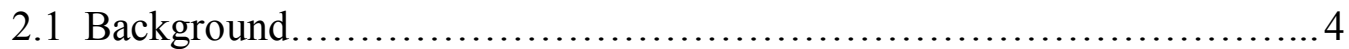

2.2 Glass Formulation......................................................

2.3 Waste Form Performance............................................. 6

2.4 Melter Technology ................................................. 6

2.5 Waste Form Qualification...........................................

2.6 Previous Repository Analyses for Can-in-Canister Waste Form........... 7

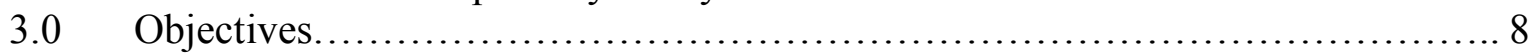

4.0 Modeling the Degradation of LaBS Glass ................................... 9

4.1 Summary of TSPA HLW Glass Degradation Model....................... 9

4.2 Testing of LaBS Glass........................................................ 11

4.3 Results of Tests with LaBS Glass.......................................... 13

4.4 Discussion............................................................... 18

5.0 Radionuclide Inventory for Immobilized Plutonium..........................27

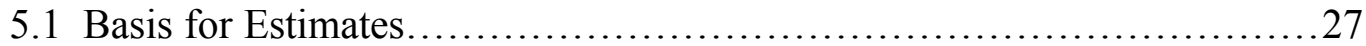

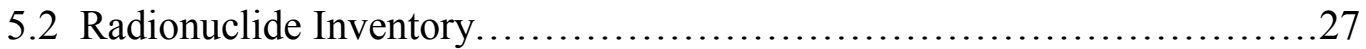

6.0 Comparison to TSPA Models................................................. 29

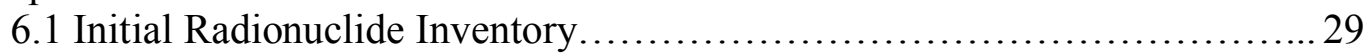

6.2 In-Package Chemistry Assessment......................................29

6.3 Dissolved Concentration Limits of Radioactive Elements.................... 30

6.4 Colloid-Associated Radionuclide Concentrations...........................31

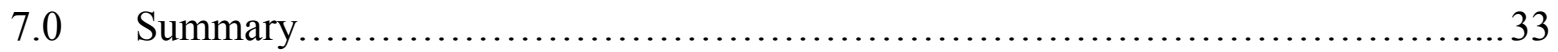

8.0 Recommendations for Future Work ......................................... 34

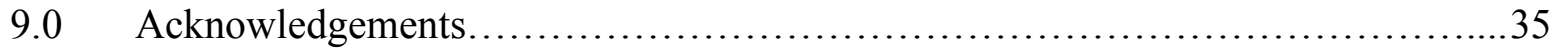

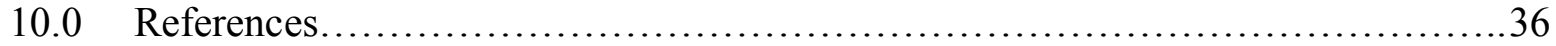




\subsection{EXECUTIVE SUMMARY}

A vitrification technology utilizing a lanthanide borosilicate (LaBS) glass appears to be a viable option for dispositioning excess weapons-useable plutonium that is not suitable for processing into mixed oxide (MOX) fuel. A significant effort to develop a glass formulation and vitrification process to immobilize plutonium was completed in the mid-1990s to support the Plutonium Immobilization Program (PIP). Further refinement of the vitrification process was accomplished as part of the Am/Cm solution vitrification project. The LaBS glass formulation was found to be capable of immobilizing in excess of $10 \mathrm{wt} \% \mathrm{Pu}$ and to be very tolerant of the impurities accompanying the plutonium material streams. Thus, this waste form would be suitable for dispositioning plutonium owned by the Department of Energy - Office of Environmental Management (DOE-EM) that may not be well characterized and may contain high levels of impurities.

The can-in-canister technology demonstrated in the PIP could be utilized to dispose of the vitrified plutonium in the federal radioactive waste repository. The can-in-canister technology involves placing small cans of the immobilized $\mathrm{Pu}$ form into a high level waste (HLW) glass canister fitted with a rack to hold the cans and then filling the canister with HLW glass. Testing was completed to demonstrate that this technology could be successfully employed with little or no impact to current Defense Waste Processing Facility (DWPF) operation and that the resulting canisters were essentially equivalent to the present HLW glass canisters to be dispositioned in the federal repository.

The performance of wastes in the repository and, moreover, the performance of the entire repository system is being evaluated by the Department of Energy - Office of Civilian Radioactive Waste Management (DOE-RW) using a Total System Performance Assessment (TSPA) methodology. Technical bases documents (e.g., Analysis/Modeling Reports (AMR)) that address specific issues regarding waste form performance are being used to develop process models as input to the TSPA analyses. In this report, models developed in five AMRs for waste forms currently slated for disposition in the repository are evaluated for their applicability to waste forms with plutonium immobilized in LaBS glass using the can-in-canister technology. Those AMRs address: high-level waste glass degradation; radionuclide inventory; in-package chemistry; dissolved concentration limits of radioactive elements; and colloid-associated radionuclide concentrations. Based on evaluation of how the models treated HLW glass and similarities in the corrosion behaviors of borosilicate HLW glasses and LaBS glass, the models in the AMRs were deemed to be directly applicable to the disposition of excess weapons-useable plutonium. The evaluations are summarized in the following paragraphs.

Defense HLW Glass Degradation Model: The release of radionuclides is calculated as the product of the HLW glass degradation rate, the glass surface area, and the radionuclide inventory of the glass. The model calculates the $\mathrm{pH}$ and temperature dependence of the glass dissolution rate directly, and uses an experimentally-based range of values to account for the variability of glass composition and water exposure conditions. The $\mathrm{pH}$-dependence of the dissolution rate of LaBS glass was consistent with that of HLW glasses in alkaline, neutral, and mildly acidic solutions. The temperature dependence of LaBS glass dissolution needs to be determined. The HLW glass degradation model was found to provide an upper bound to the degradation rate of the LaBS glass in alkaline solutions at $90^{\circ} \mathrm{C}$. 
Radionuclide Inventory: The model used for the radionuclide inventory in HLW waste uses a weighted average of the inventories in the various waste glasses expected from different production sites. That model can easily be revised to include the inventory that is immobilized in LaBS glass. The radionuclide inventory for the primary actinides was obtained for two scenarios. The first is for a case where 7 metric tonnes (MT) of plutonium is to be immobilized. This case represents a scenario where DOE-EM feeds that can not be dispositioned via the MOX fuel cycle will be dispositioned via the LaBS glass. The second case involves an upper bound for plutonium consisting of $13 \mathrm{MT}$ of plutonium and includes those feeds that appear to be suitable for the MOX cycle but for conservatism are maintained as part of the EM Pu feed inventory for immobilization.

In-Package Chemistry: The model for in-package chemistry includes the combined effects of waste form and waste package corrosion. The current model accounts for waste package configurations with HLW glass only and HLW glass co-disposed with spent fuel. The model provides the $\mathrm{pH}$ values used to calculate the HLW glass degradation rate. The range of possible $\mathrm{pH}$ values is about 2 to 11 for various waste packages and water contact conditions. The $\mathrm{pH}$ dependence of LaBS glass dissolution needs to be confirmed at low $\mathrm{pH}$ values. The model also provides the ionic strength of the solution in a breeched waste package, which is used to calculate the amounts of plutonium associated with colloids. The ionic strength of water in the waste package will be dominated by dissolution of the HLW glass embedding the LaBS glass.

Dissolved Radionuclide Concentrations: The model providing the dissolved concentration limits of radioactive elements uses an average solubility limit for crystalline and partially amorphous $\mathrm{PuO}_{2}$ to calculate the solubility limit for dissolved $\mathrm{Pu}$. $\mathrm{PuO}_{2}$ was identified as a devitrification product of LaBS glass with added plutonium. Tests showed a plutonium silicate to form as the LaBS glass degraded. This is probably a kinetically-favored precursor to the more stable oxide. Degradation of the HLW glass embedding the LaBS glass will likely establish $\mathrm{PuO}_{2}$ as the controlling phase for dissolved plutonium prior to significant degradation of the LaBS glass.

Colloid-Associated Radionuclide Concentrations: The model used to calculate colloidassociated radionuclide concentrations due to HLW glass degradation is based on the results of laboratory tests with a glass similar to the DWPF Purex glass with added plutonium. In those tests, plutonium was found fixed to colloidal clay particulates, dissolved, and sorbed to the steel test vessel. Plutonium (and americium) is modeled to be irreversibly attached to clay colloids, and the stability of those colloids in solution is correlated with the ionic strength. Because the Pu content in LaBS glass is about 100 times higher than in HLW glasses, the Pu content in the colloids generated by degradation of LaBS glass is expected to be about 100 times higher than what is calculated in the current Colloid Model. Additional testing is needed to determine if colloids form as LaBS glass degrades and to measure their Pu content. However, colloids are not currently considered to be transportable through the far field and will not have an impact on dose calculations in the safety case. 
It was determined that the models developed for TSPA calculations will adequately represent the impacts of LaBS glass degradation on repository performance. Models for HLW glass degradation, in-package chemistry, colloid-associated radionuclides, and solubility limits can be applied without modification. Revision of the HLW glass radionuclide inventory will be required because the increases in the amounts of several plutonium isotopes will exceed the range of concentrations considered in the current model. This is a simple matter of recalculating the average concentrations in waste packages that include HLW glass. It is recommended that some additional validation data on LaBS glass performance be obtained to augment the database since previous testing was not specifically aimed at evaluating repository performance. 


\subsection{INTRODUCTION}

\subsection{Background}

In the aftermath of the Cold War, the United States has identified an excess of up to 50 metric tonnes (MT) of weapons useable plutonium. To disposition this material, the Department of Energy (DOE) was to construct both a Mixed Oxide Fuel Fabrication Facility (MFFF) and a Plutonium Immobilization Plant (PIP). In April 2002, DOE decided not to construct the PIP facility and to solely proceed with the construction of the MOX facility with a focus only on the disposition of 34 metric tons of weapons grade plutonium to meet the non-proliferation agreement between Russia and the United States. This action resulted in up to 13 metric tons of EM-owned weapons usable plutonium-bearing materials having no clear disposition path.

As part of the Plutonium Immobilization Program (PIP), glass and ceramic waste forms were developed in the mid-1990s for the disposition of large quantities (up to $50 \mathrm{MT}$ ) of weaponsuseable plutonium. The final selection of a ceramic form was primarily based on the ability to incorporate higher actinide loadings into the ceramic in the case that extremely large amounts of excess $\mathrm{Pu}$ would need to be dispositioned by immobilization. Glass waste forms have been shown to easily accommodate the wide variation of impurities in nuclear wastes. It was for this reason that the United States (as well as many other countries throughout the world) selected borosilicate glass waste forms over ceramic forms for the immobilization of radioactive highlevel wastes (HLW). The wide range of impurities in the "scaled-down" scenario for immobilization of EM-owned plutonium makes borosilicate glass, namely the lanthanide borosilicate (LaBS) glass developed in PIP, an attractive candidate.

The can-in-canister technology was developed as an effective means to dispose of the plutonium waste form and provide proliferation resistance. In the can-in-canister approach, cans containing the plutonium-loaded waste form are placed in HLW glass canisters and then encapsulated with HLW glass. The can-in-canister concept was demonstrated by filling several HLW canisters loaded with cans containing Pu ceramic simulants with simulated DWPF glass (Smith, 2000). Several analyses were conducted by radioactive waste repository personnel to evaluate the viability of using the can-in-canister approach with plutonium ceramic for the disposition of the excess plutonium (B00000000-01717-4301-00006 REV 01). At that time, it was determined that disposition of the immobilized plutonium was viable and the immobilized plutonium waste form was included in site recommendation efforts. Based on these previous analyses and the degradation performance of the LaBS glass, it is anticipated that disposition of plutonium LaBS glass via the can-in-canister technology would be viable.

\subsection{Glass Formulation}

In support of the Plutonium Immobilization Program, glass formulations were developed that were shown to be capable of incorporating significant quantities of actinides as well as accommodating any impurities that may be associated with $\mathrm{Pu}$ feed streams. The impurity compositions were based on $\mathrm{Pu}$ stream inventories that were marked for immobilization. The basis for the glass formulations was from commercial glasses that had high lanthanide loadings. A development effort led to a glass that could accommodate significant quantities of actinides, tolerate impurities associated with the actinide feed streams and be readily processed using established melter technologies. Two frit compositions were developed for LaBS glass. The initial composition (Frit A) employed only gadolinium as a neutron absorber. When it was noted that incorporation of hafnium in the composition would benefit the criticality performance, hafnium replaced zirconium in the frit. Extensive testing on both systems indicated that this 
change had no bearing on the ability of the glass to incorporate actinides and impurities or on waste form performance.

Actinide Loading: To prove the technical and economic feasibility of dispositioning excess weapons usable materials, it was necessary to demonstrate that $\mathrm{PuO}_{2}$ feedstock could be readily incorporated into glass in sufficient quantities. The results of these studies showed that $\mathrm{PuO}_{2}$ solubility could be as high as $13.4 \mathrm{wt} \%(11.8 \mathrm{wt} \%$ elemental $\mathrm{Pu})$ and that these quantities could be dissolved in the glass in less than 4 hours (Vienna et al., 1996). Incorporation (complete dissolution) could be accomplished in as little as 1 hour with the assistance of agitation and/or using feed with fine particle sizes.

The solubility of combinations of plutonium and uranium was shown to be even higher than for $\mathrm{Pu}$ only. For example, a homogeneous glass containing 9 wt $\% \mathrm{PuO}_{2}$ and 6 wt $\% \mathrm{UO}_{3}$ was fabricated for a total actinide loading of 15 wt \% (Meaker and Peeler, 1997a).

It should be noted that the plutonium solubility in borosilicate glasses currently being used for high-level waste (HLW) vitrification is significantly lower than in the LaBS glass. In HLW glasses, elemental $\mathrm{Pu}$ solubility is less than $2 \mathrm{wt} \%$. The Pu content of most HLW glasses is on the order of $0.03 \mathrm{wt} \%$.

Impurity Tolerance: Component solubilities in LaBS glasses were also studied (Li et al., 1998). The results suggested that feed streams that contained $\mathrm{CaO}, \mathrm{Fe}_{2} \mathrm{O}_{3}, \mathrm{Ga}_{2} \mathrm{O}_{3}, \mathrm{~K}_{2} \mathrm{O} \mathrm{MgO}, \mathrm{MnO}$, $\mathrm{MoO}_{3}, \mathrm{Na}_{2} \mathrm{O}, \mathrm{NiO}, \mathrm{P}_{2} \mathrm{O}_{5}, \mathrm{Ta}_{2} \mathrm{O}_{5}, \mathrm{WO}_{3}$ and $\mathrm{F}$ would be good candidates for disposition via the LaBS glass. For each of these compounds the solubility in the glass was higher than any level that would be anticipated in the feed. Only chloride was found to be at levels that may not be readily incorporated in the glass. Chloride solubility in the LaBS glass was found to be $0.6 \mathrm{wt} \%$ (very typical of borosilicate glasses). Processing feed streams in excess of this would result in volatilization of chloride species. These species would need to be handled in an off-gas system. Organic contaminants would be readily decomposed at the temperatures used to process LaBS glass. However, the effects of redox reactions associated with feeds with high levels of carbon would need further evaluation.

Pu Feed Stream Solubility: Testing to evaluate the incorporation of four different "classes" of Pu feed streams was also studied as part of the Plutonium Immobilization Program efforts (Meaker and Peeler, 1997a). Average feed compositions were developed for the following classes based on composition knowledge: 1) impure oxide; 2) Pu alloy fuels (high in U); 3) Zero Power Physics Reactor (ZPPR) fuel; and 4) blending of the 17 metric tonne feed option. The following maximum loadings were determined:

1) Impure oxide (50\% $\mathrm{Pu} / 50 \%$ impurity blend): $14 \mathrm{wt} \%$ loading into the LaBS glass

2) $\mathrm{Pu}$ alloy fuels $(60 \% \mathrm{Pu} / 40 \% \mathrm{U}$ with impurity blend): $14 \mathrm{wt} \%$ loading into the $\mathrm{LaBS}$ glass

3) ZPPR fuel (30\% Pu/70\% U with impurity blend): $16 \mathrm{wt} \%$ loading into the LaBS glass

4) $17 \mathrm{MT}$ blend (60\% Pu/40\% U with impurity blend): $15 \mathrm{wt} \%$ loading into the LaBS glass. 


\subsection{Waste Form Performance}

Durability Testing: A series of laboratory tests were conducted using LaBS glass to evaluate the degradation behavior due to contact by water under different reaction conditions. For brevity, the results of these tests will not be discussed further in this section since the testing is thoroughly covered in Section 4.2.

Radiation Tolerance: During disposal, the glass will be exposed to large doses of alpha, alpha recoil, beta and gamma irradiation from the $\mathrm{Pu}$ radionuclides and their decay products in the glass. LaBS glass samples were irradiated with gamma rays and an electron beam to determine the effects of these radiations (Bibler et al., 1997). At gamma dose levels up to 3E07 Gray, there was no effect on the microstructure or durability of the glass as determined by the PCT. In electron irradiation studies (performed in a transmission electron microscope), there were no microstructural changes observed after irradiation of 8E10 Gray. A dose level of 8E10 Gray corresponds to the total ionizing radiation dose that a $10 \mathrm{wt} \% \mathrm{Pu}-239 \mathrm{LaBS}$ glass would receive from decay of all the $\mathrm{Pu}-239$ in the glass.

\subsection{Melter Technology}

Cylindrical Induction Melter (CIM): The Cylindrical Induction Melter (CIM) was developed and cold tested for use with plutonium and later pilot tested during the Americium-Curium development program (Marshall et al., 1998). The CIM system consists of an inductively heated Pt-Rh containment vessel (5" diameter), an induction heating system, a control system and a simple off-gas filtering system. The $\mathrm{Pu}$ oxide feed and frit are added batch-wise to the melter vessel and melted at approximately $1450^{\circ} \mathrm{C}$ (testing has shown that a residence time of 4 hours at $1450^{\circ} \mathrm{C}$ is adequate to incorporate the plutonium oxide into the glass). An impeller or glass pump can be incorporated into the melter to facilitate mixing and improve melt rate. The glass is discharged through the bottom of the melter by gravity through an inductively heated Pt-Rh drain tube into a stainless steel canister. During pouring, glass flow can be quickly stopped by shutting down the induction heating to the drain tube and directing air at the tip of the drain tube to "freeze" the glass. A separate chiller provides cooling water to the induction coils and heating stations for the melter and drain tube.

In surrogate testing to support $\mathrm{Pu}$ immobilization and $\mathrm{Am} / \mathrm{Cm}$ stabilization, the platinum melter performed very well. Additionally, considerable design augmentation was completed in the $\mathrm{Am} / \mathrm{Cm}$ program that would be applicable to implementation with plutonium. The melter was operated at temperatures up to $\sim 1600^{\circ} \mathrm{C}$ (note: the nominal processing temperature for the LaBS glass was $1450^{\circ} \mathrm{C}$ ), poured well, and could easily be designed to operate in a glovebox. The configuration of the unit is also compatible with local shielding, if required. Since the melter was designed to operate in the batch mode, inventory control is straightforward. Similar melters have been routinely used in industrial applications.

The CIM technology was developed with a simple off-gas system. Halide volatilization, although a concern, can be reconciled by incorporation of existing off-gas technologies and validate through further testing. 


\subsection{Waste Form Qualification}

Previous efforts to qualify HLW glass for repository disposal could be leveraged for qualification of the LaBS glass can-in-canister waste form. Extensive work was completed for HLW borosilicate glasses to develop appropriate acceptance criteria and to develop means to demonstrate that these criteria were met during production of the HLW glass waste form. These accepted strategies could be directly employed in the plutonium vitrification effort and existing documentation could be utilized for the immobilized plutonium can-in-canister waste form. Most likely a supplemental set of requirements would need to be developed for the LaBS glass and the resulting can-in-canister final waste form. An effort was initiated under the ceramic Plutonium Immobilization Program to accomplish this task (Marra et al., 2001). It is expected that minimal effort would be needed to develop and issue these requirements. Compliance documents such as a Waste Form Compliance Plan and Waste Form Qualification Report would also need to be developed. However, much of the work already performed for DWPF could be utilized.

The validation or augmentation of existing technical bases utilized in the TSPA would also be necessary for repository acceptance of the immobilized plutonium can-in-canister form. This report evaluated several of these technical bases and shows that the LaBS glass product was bounded by existing technical bases or that the necessary information could be readily obtained to augment the technical basis inputs to the TSPA.

\subsection{Previous Repository Analyses for Can-in-Canister Waste Form}

During the plutonium immobilization project, coordinated efforts were made with Yucca Mountain repository personnel to ensure that the can-in-canister waste form was consistent with proposed wastes to be disposed in the repository. Data regarding radionuclide inventories (for $\mathrm{Pu}$ inventories to be immobilized at that time), waste form performance and waste form configurations were generated and transmitted to repository personnel for analyses (Gould, 1998). The Total System Performance Assessment - Viability Assessment (TSPA-VA) Technical Basis Report completed in 1998 included analyses for the Pu ceramic can-in-canister waste form (B00000000-01717-4301-00006 REV 01). Several conclusions from that study can be cited to support the viability of disposition of a smaller quantity of excess weapons-useable plutonium using a LaBS glass waste form in a can-in-canister configuration. The analyses completed in 1998 concluded that "disposal of 50 metric tons of surplus plutonium in the repository has an insignificant effect on the dose from the entire repository." It was also concluded that the dose from the can-in-canister ceramic waste packages was nearly identical to that from an equivalent number of HLW glass canister waste packages. This analysis also showed that there was little sensitivity of the peak dose from the plutonium ceramic to a three order of magnitude increase in dissolution rate. In fact, using the HLW glass dissolution model for the degradation of the ceramic (as opposed to empirical rates for ceramic degradation) resulted in an insignificant effect on dose. The study also concluded that the peak dose from the plutonium ceramic in the can-in-canister configuration was more than three orders of magnitude lower than that from the HLW glass that encapsulated the ceramic. 


\subsection{OBJECTIVES}

In this report, the applicability of models developed in five technical bases as input to the TSPA were evaluated for their applicability to account for the impact of plutonium immobilized in LaBS glass using can-in-canister technology on the performance of the Yucca Mountain repository. The five technical models deemed to be directly applicable to the disposition of excess weapons-useable plutonium are:

1. High-level waste glass degradation

2. Radionuclide inventory

3. In-package chemistry

4. Dissolved concentration limits of radioactive elements

5. Colloid-associated radionuclide concentrations.

The objective of this effort is to examine these technical bases with regard to how HLW glass is modeled, and to either demonstrate the applicability of the existing technical bases to the LaBS glass can-in-canister waste form or identify modifications of the technical bases to account for the performance of the LaBS glass can-in-canister waste form. Primary emphasis was placed on use of the high-level waste degradation model to represent degradation of the LaBS glass, since the data and methodologies pertaining to this area are paramount to modeling waste form performance and are most specific to the waste glass. Models addressing the behavior of radionuclides released from the waste form, such as concentration limits and colloid, are independent of the waste form. 


\subsection{MODELING THE DEGRADATION OF LaBS GLASS 4.1 Summary of TSPA HLW Glass Degradation Model}

The Defense HLW Glass Degradation Model (BSC 2003a) was developed to calculate radionuclide release rates due to HLW glass degradation under a range of possible disposal conditions in the repository. The model developed for borosilicate glass dissolution is based on a well-accepted expression for the hydrolysis of an oxygen-silicon bond that was first formulated to describe dissolution of alumino-silicate minerals (Aagaard and Helgeson, 1982) and later adapted for application to borosilicate waste glass (Grambow, 1985). The model includes terms for the effects of glass composition, solution composition, solution $\mathrm{pH}$, and temperature.

$$
\text { rate }=\mathrm{k}_{0} \times 10^{\eta \mathrm{pH}} \times \exp \left(-\mathrm{E}_{\mathrm{a}} / \mathrm{RT}\right) \times(1-\mathrm{Q} / \mathrm{K})
$$

where the rate is the dissolution rate in g glass $/\left(\mathrm{m}^{2} \mathrm{~d}\right) ; \mathrm{k}_{0}$ is the intrinsic dissolution rate constant, which depends on the glass composition; $\eta$ is the $\mathrm{pH}$ dependence factor; $\mathrm{E}_{\mathrm{a}}$ is the activation energy; $\mathrm{Q}$ is the ion activity product of the solution; and $\mathrm{K}$ is the saturation product of the solution. In the case of borosilicate waste glasses, only dissolved silica is modeled to affect the rate and is included in the $\mathrm{Q}$ and $\mathrm{K}$ terms. Because glass is thermodynamically unstable, the term K represents an "apparent" saturation product at which the dissolution rate is immeasurably slow rather than a thermodynamic constant. In the TSPA glass degradation model, the terms $\mathrm{k}_{0}$ and $(1-\mathrm{Q} / \mathrm{K})$ are combined into a single term, $\mathrm{k}_{\mathrm{E}}$, which is referred to as the dissolution rate coefficient. The value of $\mathrm{k}_{\mathrm{E}}$ accounts for the effects of both glass composition and solution composition. The rate of glass dissolution used in TSPA calculations, rate $_{G}$, is

$$
\text { rate }_{G}=\mathrm{k}_{\mathrm{E}} \times 10^{\eta \mathrm{pH}} \times \exp \left(-\mathrm{E}_{\mathrm{a}} / \mathrm{RT}\right)
$$

Tests with many alumino-borosilicate glasses have indicated that the glass dissolution rate has a "V-shaped" $\mathrm{pH}$ dependence. In TSPA calculations, the $\mathrm{pH}$ of the solution in a breached codisposal waste package with HLW glass and spent nuclear fuel can range between about $\mathrm{pH} 2$ and $\mathrm{pH} 11$. Acidic solutions can result due to both corrosion of metallic components and radiolysis of moist air, and alkaline solutions can result from dealkalization of the glass. In the HLW glass degradation model, separate sets of parameter values $k_{E}, \eta$, and $E_{a}$ are used to calculate the rate in acidic and alkaline solutions; the parameter values are given in Table 1. Constant values of $\eta$ and $E_{a}$ are used, whereas the value of $k_{\mathrm{E}}$ is selected from a range and distribution of values determined from laboratory tests. The determination of the model parameter values is discussed in Section 4.4.

Application of Eq. 2 to waste glass dissolution in acidic solution is empirical. The mathematical representations of the effects of temperature and $\mathrm{pH}$ on glass dissolution in Eq. 2 are consistent with the results of tests conducted in dilute acidic solutions. Although a hydrolysis reaction is thought to control glass dissolution in acidic solutions, the authors are not aware of any tests conducted to study the effect of solution composition (other than $\mathrm{pH}$ ) on waste glass dissolution in acidic solutions. Feedback effects of dissolved alumina in acidic solutions are not expected to have the same significance as dissolved silica in alkaline solutions because of the low solubility of alumina. The maximum rate in acidic solutions calculated with the HLW glass degradation model is obtained by assigning a value of 1 to the term $(1-\mathrm{Q} / \mathrm{K})$. 
Table 1. Parameter Values Used in TSPA Glass Degradation Model

\begin{tabular}{|l|c|c|c|c|}
\hline & $\eta$ & $\mathbf{E}_{\mathbf{a}}$ & $\mathbf{k}_{\mathbf{E} \_ \text {maximum }}$ & $\mathbf{k}_{\mathbf{E} \_ \text {minimum }}$ \\
\hline For acidic solutions & -0.49 & $31 \mathrm{~kJ} / \mathrm{mol}$ & $1.15 \times 10^{7} \mathrm{~g} /\left(\mathrm{m}^{2} \mathrm{~d}\right)$ & $8.41 \times 10^{3} \mathrm{~g} /\left(\mathrm{m}^{2} \mathrm{~d}\right)$ \\
\hline For alkaline solutions & 0.49 & $69 \mathrm{~kJ} / \mathrm{mol}$ & $3.47 \times 10^{4} \mathrm{~g} /\left(\mathrm{m}^{2} \mathrm{~d}\right)$ & $2.82 \times 10^{1} \mathrm{~g} /\left(\mathrm{m}^{2} \mathrm{~d}\right)$ \\
\hline
\end{tabular}

In practice, values of $\mathrm{k}_{\mathrm{E}}$ will be selected from the distribution of values given in Table 1 for each realization in the TSPA simulation. Values of the temperature $(\mathrm{T})$ and $\mathrm{pH}$ will be provided by other models in the TSPA calculation for each time step. These values will be used in Eq. 2 with both the parameter values for acidic and alkaline solutions to calculate the dissolution rates. Rates will be calculated using both the rate expressions for acidic and alkaline solutions regardless of the solution $\mathrm{pH}$ for the time step. The higher of the two calculated rates will be used as the glass degradation rate. The radionuclide release rate (e.g., in terms of curie per day) will be calculated by multiplying the glass degradation rate by the exposed surface area and by the inventory of the radionuclide of interest. The exposed surface area of an average glass $\log , \mathrm{S}$, is calculated by using Eq. 3

$$
\mathrm{S}=\mathrm{f}_{\text {exposure }} \times 2.70 \times 10^{-3} \mathrm{~m}^{2} / \mathrm{kg} \times\left(2710 \mathrm{~kg}-\Sigma \mathrm{M}_{\mathrm{t}} \mathrm{kg}\right)
$$

where $\mathrm{f}_{\text {exposure }}$ is an exposure factor, $2.70 \times 10^{-3} \mathrm{~m}^{2} / \mathrm{kg}$ is the specific surface area of a fractured glass $\log , 2710 \mathrm{~kg}$ is the mass of an average glass $\log$, and $\Sigma \mathrm{M}_{\mathrm{t}} \mathrm{kg}$ is the total mass of glass that has degraded through time $t$. The dimensions and mass of an average glass log were calculated by assuming $67 \%$ of the glass logs will be Hanford glass in $4.5-\mathrm{m}$-long canisters, and $32 \%$ and $1 \%$ of the glass logs will be DWPF or WVDP glasses in 3.0-m-long canisters. The specific surface area is based on the geometric surface area and mass of an average glass log. The exposure factor, $f_{\text {exposure, }}$ takes into account the effects of thermal and impact cracking and the limited accessibility of water to tight cracks. It is assigned a triangular distribution over a range of values from 4 to 17 , with 4 being the most probable value.

The radionuclide inventory in HLW glasses is given in the Initial Radionuclide Inventories Model (BSC 2003b). In that model, the expected radionuclide inventories in HLW glasses from various DOE production sites are used to calculate an average concentration of the key dose contributors. The radionuclide concentrations in DWPF glass logs with embedded plutonium immobilization forms were included in the Initial Radionuclide Inventory Model used for Site Recommendation (SR), but have been excluded from the current model to be used for License Application (LA). The inventory used for LA will need to be revised to include the immobilized plutonium waste forms in the average. 


\subsection{Testing of LaBS Glass}

The feasibility of using either a lanthanide borosilicate (LaBS) glass or a titanate-based ceramic to immobilize surplus weapons-useable plutonium was evaluated in 1995-1997. Laboratory tests and analyses conducted at Argonne National Laboratory (ANL), Lawrence Livermore National Laboratory (LLNL), Pacific Northwest National Laboratory (PNNL), and the Savannah River Technology Center (SRTC) provide a database that can be used to evaluate the application of the HLW glass degradation model to the LaBS glass. Reference LaBS glass compositions were identified for immobilizing either the entire 50 MT inventory of surplus plutonium or only 18.2 MT of non-weapons pit plutonium that is unsuitable for use in reactor fuel. These are referred to as the $50 \mathrm{MT}$ and $17 \mathrm{MT}$ options, and the LaBS glass compositions are given in Table 2 (note: the term 17 MT was used to express the 18.2 MT inventory).

Two frit compositions were developed for LaBS glass. Frit A employed only gadolinium as a neutron absorber, whereas Frit B uses both gadolinium and hafnium as neutron absorbers. (Hafnium replaced zirconium in the frit composition.) Boron is not relied upon as a neutron absorber because it is released from the waste form faster than plutonium and can become separated from plutonium as the waste form degrades. The chemistries of gadolinium and hafnium are similar to that of plutonium, and these elements are expected to be released at similar rates as the LaBS glass corrodes. Both frits were used to make LaBS glasses for testing.

\section{LaBS Glass Composition}

The primary differences between LaBS glass and standard borosilicate waste glasses are the lower silica content and the absence of alkali metals in the LaBS glass. Alkali metals act as a flux in the glass melt to lower the melt temperature and serve as charge compensators for trivalent cations in the glass. LaBS glass was prepared in the laboratory by melting component oxides at $1500^{\circ} \mathrm{C}$ for 4 hours, then annealing. Preparation of LaBS glass with plutonium at SRTC resulted in a homogeneous glass with no crystals detected by either X-ray diffraction or scanning electron microscopy examination (Meaker and Bibler, 1997a).

\section{Degradation Tests}

Various laboratory tests were conducted to study the degradation behavior of LaBS glass under different reaction conditions. The test methods and the information they provide are summarized below.

MCC-1 static leach test: This test is conducted by immersing a monolithic sample of known geometric surface area in demineralized water at $90^{\circ} \mathrm{C}$ for a short duration. An amount of water (in $\mathrm{g}$ ) equal to 10 times the sample surface area $\left(\mathrm{in}^{2} \mathrm{~cm}^{2}\right.$ is used in the test. Under these conditions, components released from the glass as it dissolves are maintained at low concentrations in solution and do not significantly affect the degradation rate through solution feed-back effects. The MCC-1 static leach test has been standardized by ASTM International as Standard Test Method C1220. This test method was used to measure the $\mathrm{pH}$ and temperature dependence of the glass dissolution rate for the glass degradation model. The results of MCC-1 tests were also used to determine the maximum rate calculated by the glass degradation model in acidic solutions. 
Table 2. Measured Compositions of LaBS Glasses Prepared for Testing

\begin{tabular}{|c|c|c|c|c|c|c|c|c|c|}
\hline & \multirow{2}{*}{ Frit A } & \multirow{2}{*}{ Frit B } & \multicolumn{2}{|c|}{$\begin{array}{c}\text { Baseline Comp. } \\
\text { for }\end{array}$} & \multirow{2}{*}{$\begin{array}{c}\text { ANL } \\
\text { and } \\
\text { PNNL } \\
\text { Tests }\end{array}$} & \multicolumn{3}{|c|}{ SRTC Tests } & \multirow{2}{*}{$\begin{array}{l}\text { LLNL } \\
\text { Tests }^{\mathrm{a}}\end{array}$} \\
\hline & & & $\begin{array}{c}\text { 50-MT } \\
\text { Feed }\end{array}$ & $\begin{array}{c}\text { 17-MT } \\
\text { Feed }\end{array}$ & & Pu only & $\mathbf{P u} / \mathbf{U}$ & $\begin{array}{c}\text { Pu with } \\
\text { Impurity }\end{array}$ & \\
\hline Oxide & $\begin{array}{c}\text { Mass } \\
\%\end{array}$ & $\begin{array}{c}\text { Mass } \\
\%\end{array}$ & Mass $\%$ & Mass $\%$ & Mass $\%$ & Mass $\%$ & Mass $\%$ & Mass $\%$ & Mass \% \\
\hline $\mathrm{Al}_{2} \mathrm{O}_{3}$ & 21.5 & 21.3 & 17.9 & 17.3 & 19.3 & 18.7 & 18.1 & 18.3 & 15.2 \\
\hline $\mathrm{B}_{2} \mathrm{O}_{3}$ & 11.7 & 11.6 & 9.7 & 9.4 & 9.69 & 10.2 & 9.9 & 10.0 & 3.1 \\
\hline $\mathrm{Gd}_{2} \mathrm{O}_{3}$ & 8.6 & 12.8 & 10.8 & 10.4 & 8.01 & 7.42 & -- & -- & -- \\
\hline $\mathrm{HfO}_{2}$ & -- & 6.6 & 5.5 & 5.3 & -- & -- & 5.6 & 5.7 & -- \\
\hline $\mathrm{La}_{2} \mathrm{O}_{3}$ & 12.4 & 8.1 & 6.8 & 6.6 & 11.3 & 11.3 & $24.7^{\mathrm{b}}$ & $25.0^{\mathrm{b}}$ & 15.6 \\
\hline $\mathrm{Nd}_{2} \mathrm{O}_{3}$ & 12.8 & 8.2 & 6.9 & 6.6 & 12.4 & 10.3 & & & 18.7 \\
\hline $\mathrm{PuO}_{2}$ & -- & -- & 10.0 & 8.0 & 11.9 & 9.06 & 9.0 & 6.6 & -- \\
\hline $\mathrm{SiO}_{2}$ & 29.2 & 28.9 & 24.3 & 23.4 & 25.0 & 29.8 & 24.6 & 24.8 & 24.6 \\
\hline $\mathrm{SrO}$ & 2.5 & 2.5 & 2.1 & 2.0 & 2.36 & 2.18 & 2.1 & 2.1 & -- \\
\hline $\mathrm{UO}_{3}$ & -- & -- & 3.0 & 8.0 & -- & -- & 6.0 & -- & -- \\
\hline $\mathrm{ZrO}_{2}$ & 1.3 & -- & -- & -- & 1.20 & 1.07 & -- & -- & -- \\
\hline $\begin{array}{l}\text { Impurities, } \\
\text { as oxides }\end{array}$ & & -- & 3.0 & 3.0 & -- & -- & -- & 7.4 & -- \\
\hline
\end{tabular}

${ }^{\mathrm{a}}$ Loeffler glass also contains $3.6 \mathrm{wt} \% \mathrm{BaO}, 9.4 \mathrm{wt} \% \mathrm{PbO}$, and $9.8 \mathrm{wt} \% \mathrm{CeO}_{2}$ as a surrogate for $\mathrm{PuO}_{2}$.

${ }^{\mathrm{b}}$ Concentration reported as combined rare earth elements.

Product Consistency Test (PCT): This test is conducted by immersing a known mass of crushed glass in demineralized water. The PCT has been standardized by ASTM International as Standard Test Method C1285. The PCT Method A test is conducted under specific test conditions: $90^{\circ} \mathrm{C} ; 7$ days; $-100+200$ mesh-size glass; water/glass mass ratio of 10 . The PCT Method B allows for varying the test conditions (temperature, duration, and glass/water mass ratio are commonly varied). Under PCT conditions, components that are released from the glass as it dissolves accumulate in the solution throughout the test and affect the degradation rate through solution feedback effects. The primary feedback effects are by dissolved silica and increased $\mathrm{pH}$. The extent of degradation under these tests conditions can be compared with that of other waste forms. A current acceptance criterion is that the PCT Method A response must be less than the response of the Environmental Assessment (EA) benchmark glass, after normalizing the glass compositions (USDOE EM-0093, 1996). The average rate in the PCT Method A test, based on the amount of boron released over 7 days, was used to determine the maximum rate calculated by the HLW glass degradation model in alkaline solutions. 
Vapor Hydration Test (VHT): In this test method, a monolithic sample is exposed to water vapor in a closed vessel at an elevated temperature. The glass reacts with a thin film of water that condenses on the sample due to the hygroscopic nature of the glass. The release of alkali metals from HLW glass lowers the vapor pressure of the film and causes more vapor to condense. The film of water quickly becomes concentrated in dissolved glass species, and may become saturated with respect to other phases, which precipitate from solution onto the reacted glass surface. The evolution of the solution chemistry in a VHT mimics the evolution that will occur over long times in a less aggressive environment. Information provided by these tests includes insight into the degradation behavior of the glass, a measure of the degradation rate in concentrated solutions, and identification of solid alteration phases. The results of VHTs conducted with reference glasses at elevated temperatures were extrapolated to $90^{\circ} \mathrm{C}$ and used to determine the minimum rate calculated by the TSPA glass degradation model in alkaline solutions.

Single-Pass Flow-Through (SPFT) Test: This test is designed to measure the glass dissolution rate in a solution with a controlled or imposed $\mathrm{pH}$. Solution is passed through a cell containing glass (which may be a monolithic or crushed sample) at a flow rate high enough that the components released into the solution as the glass dissolves do not influence the dissolution rate. That is, the value of $(1-\mathrm{Q} / \mathrm{K})$ is maintained near 1 . These tests can be used to measure the $\mathrm{pH}$ and temperature dependence of the glass dissolution rate.

\section{Normalized Elemental Mass Loss}

The extent of degradation is usually expressed as the normalized mass loss based on element $\mathrm{i}$, NL(i), which is calculated from the solution concentration of a soluble element, C(i), the mass fraction of that element in the glass $\mathrm{f}(\mathrm{i})$, and the glass surface area-to-solution volume ratio of the test $(\mathrm{S} / \mathrm{V})$ as given in Eq. 4. NL(i) has units of mass glass per unit area.

$$
\mathrm{NL}(\mathrm{i})=\mathrm{C}(\mathrm{i}) /[(\mathrm{S} / \mathrm{V}) \times \mathrm{f}(\mathrm{i})]
$$

The normalized dissolution rate is calculated as $\Delta \mathrm{NL}(\mathrm{i}) / \Delta \mathrm{t}$, where $\mathrm{t}$ is the test duration, if results are available for several durations, or as NL(i)/t if data are available for only one test duration, as for 7-day PCT Method A tests. The PCT results are sometimes reported in terms of the normalized concentration, $\mathrm{NC}(\mathrm{i})$, which is simply

$$
\mathrm{NC}(\mathrm{i})=\mathrm{C}(\mathrm{i}) / \mathrm{f}(\mathrm{i})
$$

\subsection{Results of Tests with LaBS Glass}

MCC-1 Static Leach Tests

Triplicate 3-day MCC-1 static leach tests were conducted at $90^{\circ} \mathrm{C}$ (Mertz et al. 1996). The results of such short duration tests are not expected to be affected by solution feedback effects to a significant extent, but are expected to be sensitive to the surface finish of the test samples. That is, the initial test response is probably dominated by the dissolution of fines and glass at high-energy sites (such as the edges of polishing scratches). These test results provide a conservative upper bound to the initial dissolution rate that can be compared with SPFT test results. The 3-day MCC-1 test results are summarized in Table 3. 
Table 3. Results of MCC-1 Static Leach Tests with LaBS Glass

\begin{tabular}{|c|c|c|c|c|c|c|}
\hline \multirow{2}{*}{ Test No. } & \multirow{2}{*}{$\mathbf{S} / \mathbf{V}, \mathbf{m}^{-\mathbf{1}}$} & $\mathbf{p H}$ & \multicolumn{5}{|c|}{ Normalized Mass Loss, $\mathbf{g} / \mathbf{m}^{\mathbf{2}}$} \\
\cline { 4 - 7 } & & & $\mathbf{B}$ & $\mathbf{S i}$ & $\mathbf{P u}$ & $\mathbf{G d}$ \\
\hline 1 & 10.0 & 5.3 & 2.1 & 1.5 & 0.22 & 0.8 \\
\hline 2 & 9.99 & 4.9 & 2.5 & 1.9 & 0.23 & 1.0 \\
\hline 3 & 9.99 & 5.1 & 2.9 & 2.2 & 0.25 & 1.2 \\
\hline average & & 5.1 & 2.5 & 1.9 & 0.23 & 1.0 \\
\hline
\end{tabular}

The dissolution of HLW glasses results in alkaline solutions due to dealkalization reactions. The LaBS glass does not contain alkali metals, and the measured $\mathrm{pH}$ probably reflects the effect of dissolved $\mathrm{CO}_{2}$.

Product Consistency Tests with LaBS Glass

PCT Method A and Method B Tests: Duplicate 7-day PCT Method A static leach tests were conducted at $90^{\circ} \mathrm{C}$ at an $\mathrm{S} / \mathrm{V}$ ratio of $2000 \mathrm{~m}^{-1}$ (Mertz et al. 1996). The PCT Method A procedure calls for using a water/glass mass ratio of 10 . Borosilicate waste glasses have a density of about $2.7 \mathrm{~g} / \mathrm{cm}^{3}$, so crushed glass in the $-100+200$ mesh size range has a specific surface area of about $2.0 \times 10^{-2} \mathrm{~m}^{2} / \mathrm{g}$ and a water/glass mass ratio of 10 gives an $\mathrm{S} / \mathrm{V}$ ratio of about $2000 \mathrm{~m}^{-1}$. The LaBS glass has a density of about $4.75 \mathrm{~g} / \mathrm{cm}^{3}$, so crushed LaBS glass in the $-100+200$ mesh size range has a specific surface area of about $1.2 \times 10^{-2} \mathrm{~m}^{2} / \mathrm{g}$. A water/glass mass ratio of 6 is required to attain an $\mathrm{S} / \mathrm{V}$ ratio of $2000 \mathrm{~m}^{-1}$ in PCT with LaBS glass. Direct comparison with the results of PCT with borosilicate glass and with the EA benchmark glass requires that PCTs be conducted at the same $\mathrm{S} / \mathrm{V}$ ratio, not the same water/glass mass ratio. Other PCTs (using PCT Method B) were conducted for longer durations at a water/glass mass ratio of about 0.6 to achieve an $\mathrm{S} / \mathrm{V}$ ratio of $\sim 20,000 \mathrm{~m}^{-1}$. Test results are summarized in Table 4 . The $\mathrm{pH}$ of the PCT solution was measured at room temperature. Tests at higher $\mathrm{S} / \mathrm{V}$ ratios are used to accelerate the increase in solution concentrations to accelerate the reaction progress. Tests at higher $\mathrm{S} / \mathrm{V}$ ratios do not accelerate the glass degradation rate, although this is often stated in error. In fact, conducting tests at higher $\mathrm{S} / \mathrm{V}$ ratios usually lowers the glass degradation rate because the solution feedback effects are more significant. Note that the normalized mass losses of B (and Si) in tests conducted for 7 days at $2000 \mathrm{~m}^{-1}$ and for 98 days at $20,000 \mathrm{~m}^{-1}$ are similar. The average rate in the 7-day test at $2000 \mathrm{~m}^{-1}$ (which is about $0.01 \mathrm{~g} /\left(\mathrm{m}^{2} \mathrm{~d}\right.$ ) for boron) is clearly higher than that in the 98 -day test at $20,000 \mathrm{~m}^{-1}$ (which is about $0.0007 \mathrm{~g} /\left(\mathrm{m}^{2} \mathrm{~d}\right)$ for boron). 
Table 4. Results of PCT with LaBS Glass

\begin{tabular}{|c|c|c|c|c|c|c|c|}
\hline \multirow{2}{*}{ Test No. } & \multirow{2}{*}{$\mathbf{S} / \mathbf{V}, \mathbf{m}^{-1}$} & \multirow{2}{*}{ Duration, $\mathrm{d}$} & \multirow{2}{*}{ pH } & \multicolumn{4}{|c|}{ Normalized Mass Loss, $\mathbf{g} / \mathbf{m}^{2}$} \\
\hline & & & & B & $\mathbf{S i}$ & $\mathbf{P u}$ & Gd \\
\hline 1 & 2080 & 7 & 8.1 & 0.060 & 0.026 & 0.010 & 0.003 \\
\hline 2 & 1950 & 7 & 8.0 & 0.077 & 0.024 & 0.009 & 0.003 \\
\hline average & & 7 & 8.1 & 0.069 & 0.025 & 0.010 & 0.003 \\
\hline 3 & 19800 & 28 & 8.2 & 0.048 & 0.017 & 0.013 & 0.014 \\
\hline 4 & 19500 & 98 & 8.8 & 0.072 & 0.025 & 0.010 & 0.016 \\
\hline 5 & 19700 & 182 & 8.5 & 0.068 & 0.020 & 0.0084 & 0.0072 \\
\hline
\end{tabular}

Note that the values of NL(B) are higher than the values of $\mathrm{NL}(\mathrm{Si}), \mathrm{NL}(\mathrm{Pu})$, and $\mathrm{NL}(\mathrm{Gd})$ in all tests. This indicates that the degradation rate of the glass matrix, as indicated by the release of $\mathrm{B}$, bounds the releases of $\mathrm{Si}, \mathrm{Pu}$, and $\mathrm{Gd}$. Note also the similarities in the values of $\mathrm{NL}(\mathrm{Pu})$ and $\mathrm{NL}(\mathrm{Gd})$ for different test conditions. It is important that the disposition of these elements because Gd is used as a neutron absorber. The MCC-1 tests showed a slightly preferential release of $\mathrm{Gd}$ relative to $\mathrm{Pu}$ in dilute conditions. The more concentrated solutions generated in the PCTs are more representative of likely disposal conditions where only small amounts of water will contact the waste forms.

Effects of Impurities in LaBS Glass: The predominant impurities in the surplus plutonium include B (0.13), Ba, Ca, Cl (1.7), Cr (0.11), F (0.45), Fe (0.45), Ga (1.1), K, Mg, Mo (0.45), Na (0.45), Ni (0.32), rare earth elements, Si (0.85), Ta (0.65), W (1.7), Zn (0.10), and Zr. The numbers in parentheses following some elements are the maximum expected mass $\%$ of that element in the waste stream. The effect of impurities in the waste stream on the durability of the LaBS glass was measured using a 7-day PCT (Method A) with glasses made with Pu only, with $\mathrm{Pu}$ and $\mathrm{U}$, and with $\mathrm{Pu}$ and a mixture of impurities (Meaker and Bibler, 1997a). As shown in Table 5, the presence of $U$ and impurities actually increases the durability of the LaBS glass, although the difference may be due to differences in the rare earth and zirconium contents, as well. Note that these results should not be compared to the results in Table 4 because these tests were conducted at a water/glass mass ratio of 10 .

Table 5. Results of PCT with LaBS Glass Containing Impurities

\begin{tabular}{|l|c|c|c|c|c|c|}
\hline \multirow{2}{*}{} & \multicolumn{7}{|c|}{ Normalized Concentration, g/L } \\
\cline { 2 - 7 } & $\mathrm{B}$ & $\mathrm{La}$ & $\mathrm{Nd}$ & $\mathrm{Si}$ & $\mathrm{Sr}$ & $\mathrm{Pu}$ \\
\hline $\mathrm{Pu}$ only & 0.026 & -- & -- & 0.019 & 0.027 & 0.013 \\
\hline $\mathrm{Pu} / \mathrm{U}$ & 0.020 & 0.0012 & 0.00024 & 0.016 & 0.021 & 0.0044 \\
\hline $\mathrm{Pu} / \mathrm{Impure}$ & 0.014 & 0.0018 & 0.00068 & 0.013 & 0.017 & 0.0035 \\
\hline
\end{tabular}


Phase Stability of LaBS Glass: Devitrification of LaBS glass was induced by reheating to $990^{\circ} \mathrm{C}$ over 2 hours then slow cooling (about $1^{\circ} \mathrm{C} /$ minute). Crystallites of $\mathrm{PuO}_{2}$ were detected with $\mathrm{X}$-ray diffraction and observed to be uniformly distributed throughout the sample with SEM (Meaker and Bibler, 1997b). Seven-day PCTs (Method A) were conducted with samples of both homogeneous (amorphous) and devitrified LaBS glasses. The results are summarized in Table 6. Devitrification did not affect the release of $\mathrm{B}, \mathrm{Si}$, or $\mathrm{Sr}$, but did result in a decrease in the release of $\mathrm{Pu}$. A lower release of $\mathrm{Pu}$ in the devitrified material was also observed in 45-day PCTs. This is because the $\mathrm{Pu}$ content of the glass was lowered by the formation of $\mathrm{PuO}_{2}$ crystallites, which are more durable than the glass. These results should not be compared to the results in Table 4 because these tests were conducted at a water/glass mass ratio of 10 .

It should be noted that devitrification of the plutonium glass waste form to this extent is highly unlikely to occur during production of the can-in-canister waste forms. Testing was performed in PIP to demonstrate that HLW could be poured in canisters containing a prototypic configuration of $\mathrm{Pu}$ waste form cans without forming voids or unacceptably changing the canister or the canister internal assembly (Smith, 2000). As part of the pour testing, thermocouples were placed throughout the canister to obtain temperature profiles during the canister fill and cool-down processes. The maximum temperature a can containing the $\mathrm{Pu}$ waste form experienced was $900^{\circ} \mathrm{C}$. The cool-down from this temperature occurred essentially instantaneously and was down to $800^{\circ} \mathrm{C}$ within 2 hours. This maximum temperature was for the outer surface of can at the highest location in the canister and for the area of the can facing the center of the canister. The maximum temperatures measured were less than $800^{\circ} \mathrm{C}$ for cans at all other locations (e.g. area of a can facing the canister wall for cans at a similar height and for cans at all other heights). Therefore, it is expected that the maximum temperature the waste form inside the can would experience would be appreciably lower than $900^{\circ} \mathrm{C}$. Time-temperaturetransformation (TTT) testing for the LaBS glass showed that devitrification only consistently occurred in glasses that were heated to temperatures of $1000^{\circ} \mathrm{C}$ or above (Meaker and Peeler, 1997c). Glasses heated to $900^{\circ} \mathrm{C}$ only showed signs up devitrification if held at that temperature for 2 hours and then slow cooled. Glasses heated to $800^{\circ} \mathrm{C}$ did not devitrify even when held at that temperature for up to 24 hours.

Table 6. NC(i) for PCT with Amorphous and Devitrified LaBS Glasses

\begin{tabular}{|c|c|c|c|c|}
\hline \multirow{2}{*}{} & \multicolumn{4}{|c|}{ Normalized Concentration, g/L } \\
\cline { 2 - 5 } & $\mathbf{B}$ & $\mathbf{S i}$ & $\mathbf{S r}$ & $\mathbf{P u}$ \\
\hline Amorphous & 0.026 & 0.019 & 0.027 & 0.017 \\
\hline Devitrified & 0.029 & 0.020 & 0.030 & 0.0036 \\
\hline
\end{tabular}


Vapor Hydration Tests with LaBS Glass

Vapor hydration tests were conducted at $200^{\circ} \mathrm{C}$ for $7,14,21,35$, and 56 days (Mertz et al. 1996). A white alteration phase formed on all test samples, with the amount increasing with the test duration. These were dispersed throughout an aluminosilicate alteration phase. The white alteration phase was characterized with analytical electron microscopy to be a crystalline $\mathrm{Pu}$ - and rare earth-bearing silicate phase. From X-ray absorption spectroscopy, the rare earth element-toplutonium ratio is higher in the alteration phase than in the LaBS glass (Mertz et al. 1996). This suggests that another Pu-bearing phase is formed in the VHTs, although it was not detected. For example, $\mathrm{PuO}_{2}$ formed as a devitrification phase in heat treated samples and may also form in the VHTs.

Single-Pass Flow-Through Tests with LaBS Glass

A series of SPFT tests were conducted at $90^{\circ} \mathrm{C}$ with solutions buffered at $\mathrm{pH}$ values (calculated at $90^{\circ} \mathrm{C}$ ) of about 5.9, 7.6, 8.6, 9.2, 9.4, and 10.4 (Strachan et al., 1997 Figure 3). These tests were conducted to measure the dissolution rate in the absence of solution feedback effects from dissolved glass components. The results of tests with material PNL30-11.39Pu (a LaBS glass containing $11.39 \%$ elemental $\mathrm{Pu}$ ) are plotted in Figure 1. The SPFT rates are based on the release of silicon and aluminum. The $\mathrm{pH}$ dependence coefficient in alkaline solutions is $\eta=$ 0.437. Sufficient SPFT test data are not available to determine the $\mathrm{pH}$ dependence in acidic solutions, but the rate measured at $\mathrm{pH} 5.9$ is consistent with an increase in the rate as the $\mathrm{pH}$ decrease from neutral (i.e., a V-shaped $\mathrm{pH}$ dependence curve). The rate measured in the MCC-1 tests (based on the release of boron) can be used to estimate the $\mathrm{pH}$ dependence in acidic solutions. The average of the $\mathrm{pH}$ values measured at room temperature is 5.1 (see Table 3 ). The $\mathrm{pH}$ of a dilute solution is expected to increase about $0.8 \mathrm{pH}$ units as the temperature decreases from $90^{\circ} \mathrm{C}$ to room temperature due to the change in the ion product of water $\left(\mathrm{pK}_{\mathrm{w}}\right.$ is 12.4 at $90^{\circ} \mathrm{C}$ and 14.0 at $24^{\circ} \mathrm{C}$ ). The solution $\mathrm{pH}$ at $90^{\circ} \mathrm{C}$ is estimated to be 4.3 . From this value and the value measured with the SPFT test, the $\mathrm{pH}$ coefficient for acidic solutions is $\eta=-0.304$. Since the rate from the MCC-1 test is expected to be conservatively high, the $\mathrm{pH}$ dependence is probably conservatively steep.

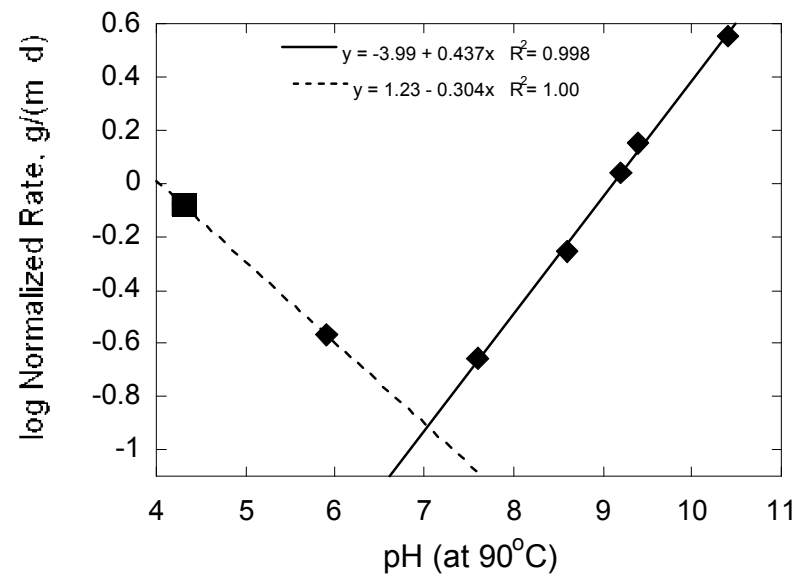

Figure 1. Rates Measured with Single-Pass Flow-Through Tests $(\diamond)$ and 3Day MCC-1 Tests (ם) with LaBS Glass vs. pH Calculated at $90^{\circ} \mathrm{C}$. The solid line is regressed to the rates measured in alkaline solutions and the dashed line is regressed to the rates measured in acidic solutions. 


\subsection{Discussion}

Approach for Comparing HLW Glass Degradation Model to LaBS Glass Corrosion

Consideration of how the HLW glass degradation model was developed and how the glass degradation rate and radionuclide release is calculated is helpful in evaluating whether or not the model can be used to represent the release of radionuclides from other waste forms. The objective of the HLW glass degradation model is to provide the glass degradation rate under the range of environmental conditions simulated in TSPA calculations. Whereas the glass degradation rate is known to depend on the glass composition, the solution composition, $\mathrm{pH}$, and temperature, the HLW glass degradation model only includes terms to specifically calculate the $\mathrm{pH}$ and temperature dependence. The effects of the glass composition, solution composition, and volume of water contacting the glass are included in a single term referred to as the dissolution rate coefficient, $\mathrm{k}_{\mathrm{E}}$. In the HLW glass degradation model, a simplified expression for the mechanistic rate expression is used and various test results are used to determine the model parameter values. Tests conducted under different water contact conditions were used to ensure the range of the rate coefficient accounted for degradation due to contact by water vapor and dripping water as well as by immersion.

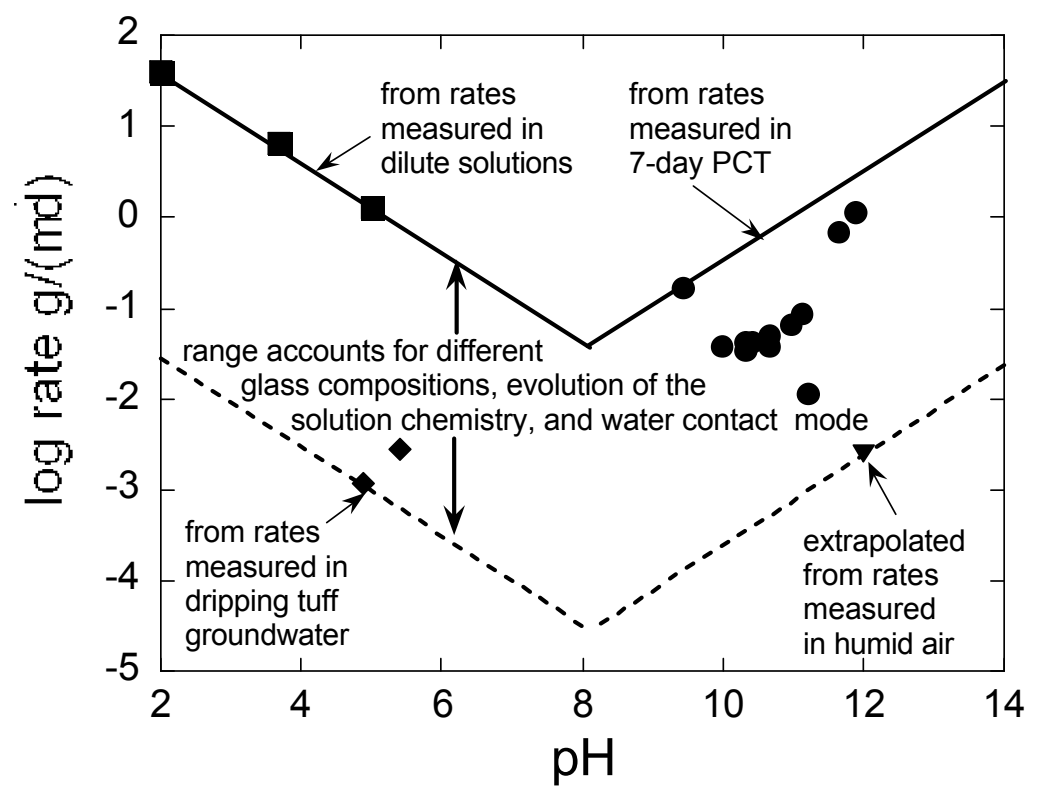

Figure 2. Plot of Maximum and Minimum Rates for HLW Glass Degradation Model at $90^{\circ} \mathrm{C}$ and Data Used to Calibrate Model.

Figure 2 illustrates how the HLW glass degradation model was calibrated using the rates measured in different laboratory tests. The $\mathrm{pH}$ and temperature dependencies were first determined for a glass having a composition similar to the design basis glass for the DWPF using short-term MCC-1 tests in solutions with induced $\mathrm{pH}$ values. Under those test conditions, glass dissolution did not significantly change the solution $\mathrm{pH}$ and the value of the affinity term remained nearly 1 . The rates measured with MCC-1 tests were used directly to determine the maximum rate for acidic solutions, since the solution feedback effects are expected to be 
negligible in acidic solutions regardless of the amount of glass that has degraded. The rates measured in the tests are shown by the squares in Fig. 3.

The average rates measured in 7-day PCTs were used to bound the effect of solution feedback on the dissolution rate in alkaline solutions. The results of 7-day PCTs conducted with glasses providing a wide composition range were used to select a bounding rate for the maximum rate in alkaline solutions. The PCT results are shown by the circles in Fig. 3. The maximum values of $\mathrm{k}_{\mathrm{E}}$ for acidic and alkaline solutions were determined by solving Eq. 2 using the experimentally measured rates for rate $_{G}$ and the measured $\mathrm{pH}$ with values of $\eta$ and $\mathrm{E}_{\mathrm{a}}$ measured with the MCC-1 tests.

The minimum rates in acidic solutions were determined from unsaturated (drip) tests. The solutions in those tests attained an acidic solution $\mathrm{pH}$, probably due to corrosion of metallic components in the test vessel and perhaps also to radiolysis. These tests provided a direct measurement of the release of boron (and some radionuclides) from reference waste glasses contacted by periodically dripping water over about 16 years. The minimum rates in alkaline solutions were determined from VHTs with several reference HLW glasses. The rates measured at high temperatures were used to determine an effective activation energy, then the rate at $90^{\circ} \mathrm{C}$ was determined by extrapolation. The values of $\mathrm{k}_{\mathrm{E}}$ for the minimum rates in acidic and alkaline solutions were selected such that the calculated rates matched the rates measured in the unsaturated (drip) tests and in the VHTs at those particular $\mathrm{pH}$ values, respectively. The diamond and triangle symbols in Fig. 3 show the correspondence of the measured and calculated rates.

The minimum rates are the most probable rates in the distributions used for TSPA calculations because they were determined from tests conducted under the most likely water contact conditions, namely condensed water vapor and slowly dripping groundwater. However, the ability of the glass degradation model to represent alternative waste forms is evaluated based on the maximum rates.

Comparison of Measured Degradation Behavior of LaBS Glass with HLW Glass Degradation Model

Application of the HLW glass degradation model to LaBS glass is predicated on the common dissolution behaviors of standard borosilicate glasses and the LaBS glass observed in laboratory tests. Key aspects of the dissolution behavior are the dependence of the rate on the solution $\mathrm{pH}$ and temperature, the impact of solution feedback effects on the dissolution rate, and the relative release rates of glass matrix components (particularly boron) and radionuclides. Insight from the results of tests with LaBS glass discussed in Section 4.3 is compared with particular aspects of HLW glass degradation and how they are treated in the HLW glass degradation model.

$p H$ : Dissolution of LaBS glass follows the same $\mathrm{V}$-shaped $\mathrm{pH}$ dependence that has been observed for many borosilicate glasses and is modeled in the HLW glass degradation model. Figure 3 shows a direct comparison of the $\mathrm{pH}$-dependence measured for the LaBS glass (solid lines) with the $\mathrm{pH}$ dependence used to develop the HLW glass degradation model (dashed lines) (BSC 2003a, Figure 6.5-2). The plot is shown for the $\mathrm{pH}$ at room temperature. The equations for the fit lines from Figure 1 are shown shifted by $0.8 \mathrm{pH}$ units to account for the difference in $\mathrm{pH}$ at room temperature and at $90^{\circ} \mathrm{C}$. The parameter values for the $\mathrm{pH}$ dependence in the HLW glass degradation model are seen to represent the dependence measured for the LaBS glass well. The $\mathrm{pH}$ dependence is the same in alkaline solutions, within experimental uncertainty, and the 
$\mathrm{pH}$ dependence in the model for acidic solutions provides an upper bound for the $\mathrm{pH}$ dependence of LaBS glass except at neutral $\mathrm{pH}$ values. The $\mathrm{pH}$ dependence used in HLW glass degradation model for acidic solutions is steeper than that measured for the LaBS glass. The $\mathrm{pH}$ dependence of the LaBS glass dissolution rate measured in acidic solutions is considered to be more uncertain than the rate in alkaline solutions.

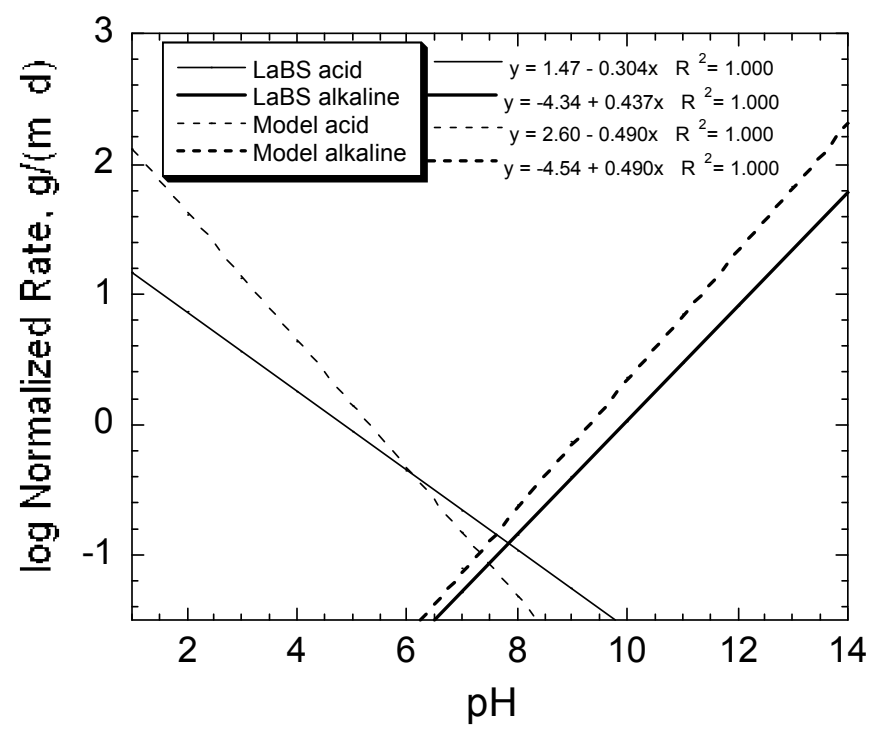

Figure 3. Comparison of pH Dependence in Acidic and Alkaline Solutions Measured for LaBS Glass with Dependence in HLW Glass Degradation Model. (The pH values for LaBS glass were shifted 0.8 units to estimate $\mathrm{pH}$ at room temperature.)

The $\mathrm{pH}$ of the solution that accumulates in a breached waste package is calculated for use in TSPA by the In-Package Chemistry Abstraction Model (BSC 2003b). That model provides separate chemistries for water collected in packages with commercial spent nuclear fuel (referred to as CSNF packages) and in co-disposal packages with HLW glass and defense (Hanford Nreactor) spent nuclear fuel (referred to as CDNR packages). The chemistries are determined for two amounts of solution that represent the accumulation of condensed water vapor and seepage water. Both are referred to as thin water films. For CDNR packages, the film generated by condensed water vapor is $0.2 \mathrm{~cm}$ thick and the film generated by seepage water is $0.35 \mathrm{~cm}$ thick. These thicknesses provided the minimum volumes of water for which the chemistries could be reliably calculated (ANL-EBS-MD-000037 Rev 2, Section 5.3). The In-Package Chemistry Abstraction Model uses the HLW glass and fuel degradation rates provided by Defense HLW Glass Degradation Model (BSC 2003a) and the DSNF and Other Waste Form Degradation Abstraction Model (BSC 2003c). The In-Package Chemistry Abstraction Model provides ranges of $\mathrm{pH}$, Eh, ionic strength values and carbonate, fluoride, chloride concentration values based on the simultaneous corrosion of the HLW glass and fuel in a co-disposal waste package and the corrosion of metal components (including the waste package and structural components) under both condensed water vapor and seepage water conditions. Only the $\mathrm{pH}$ value is used in the glass degradation model. The $\mathrm{pH}$ range calculated for possible combinations of waste form and metal components under potential vapor or water seepage conditions plus uncertainties covers the range from about $\mathrm{pH} 2$ to $\mathrm{pH} 11$. 
Temperature: The temperature dependence of HLW glass dissolution rate is modeled using the Arrhenius form. Dissolution of LaBS glass is likewise expected to have an Arrhenius temperature dependence, although the temperature dependence of the LaBS dissolution rate has not been measured. Results of SPFT tests with LaBS glass are only available at $90^{\circ} \mathrm{C}$. However, the results of SPFT tests conducted at LLNL at $70^{\circ} \mathrm{C}$ with the Loeffler glass may provide insight into the temperature dependence. This is a commercial glass with a high lanthanide content and similar aluminum and silicon contents as the LaBS glass. As shown in Table 2, the compositions of the Loeffler and LaBS glasses are similar with regard to $\mathrm{Al}, \mathrm{Si}$, and rare earth elements. Ceria $\left(\mathrm{CeO}_{2}\right)$ is often used as a surrogate for $\mathrm{PuO}_{2}$, and the concentrations of these oxides are similar in the two glasses. The LaBS glass has a much higher B content than the Loeffler glass, but that is not expected to have a significant effect on the glass durability. The measured rates plotted in Fig. 4 of Strachan et al. (1998) indicate that the dissolution rates of the LaBS and Loeffler glasses have the same $\mathrm{pH}$ dependence. The dissolution rates at $\mathrm{pH} 6$ and $\mathrm{pH} 8$ were determined graphically from the lines that were fit to the data by Strachan et al. (1998). The lines in Fig. 4 reproduce the bold lines in Fig. 4 of Strachan et al. (1998). (Note that the $\mathrm{pH}$ dependence of the alkaline leg at $90^{\circ} \mathrm{C}$ is slightly higher than determined in Fig. 1.) The rates at $\mathrm{pH} 6$ and $\mathrm{pH} 8$ were used to calculate effective activation energy values for the acidic and alkaline legs using the following expression:

$$
\mathrm{E}_{\mathrm{a}}=\mathrm{R} \times \ln \left[\left(\text { rate } 90^{\circ} \mathrm{C}\right) /\left(\text { rate } 70^{\circ} \mathrm{C}\right)\right] \div(1 / 343-1 / 363)
$$

where $\mathrm{R}$ is the ideal gas constant $\mathrm{R}=8.314 \mathrm{~J} /(\mathrm{mol} \mathrm{K})$. The values of $\log$ rate that were read from the plot in Fig. 4 of Strachan et al. (1998) and the corresponding values of the rates are summarized in Table 7.

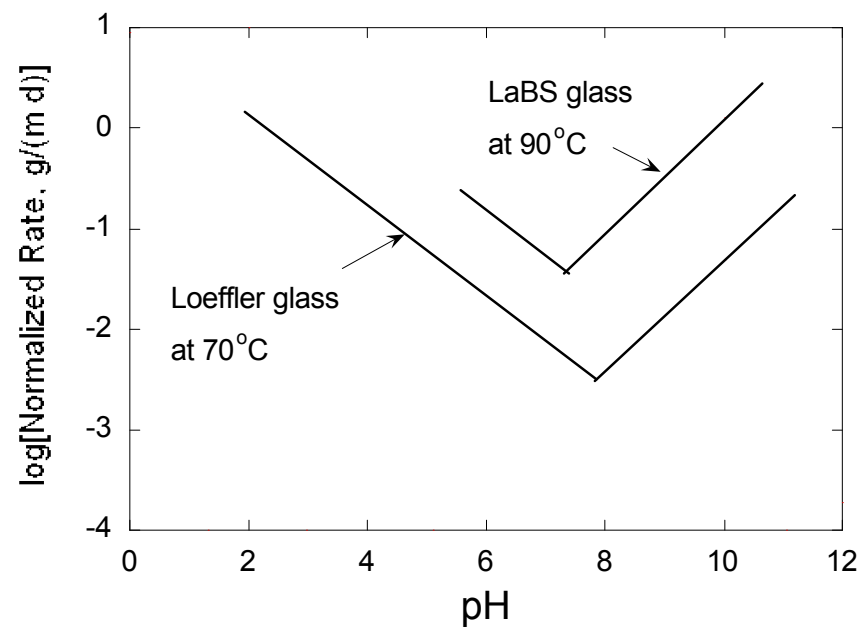

Figure 4. Comparison of SPFT Test Results with LaBS Glass and Loeffler Glass. 
Table 7. Dissolution Rates for Acid and Alkaline Legs

\begin{tabular}{|c|c|c|c|c|}
\hline & \multicolumn{2}{|c|}{ Acid Leg at $\mathbf{p H} 6$} & \multicolumn{2}{c|}{ Alkaline Leg at $\mathbf{p H ~ 8}$} \\
\hline & $\log$ rate & rate, $\mathbf{g} /\left(\mathbf{m}^{\mathbf{2}} \mathbf{d}\right)$ & $\log$ rate & rate, $\mathbf{g} /\left(\mathbf{m}^{\mathbf{2}} \mathbf{d}\right)$ \\
\hline $90^{\circ} \mathrm{C}$ & -0.88 & 0.132 & -1.11 & 0.0769 \\
\hline $70^{\circ} \mathrm{C}$ & -1.71 & 0.0195 & -2.41 & 0.00389 \\
\hline
\end{tabular}

These rates were used with Equation 6 to calculate values of the activation energy for acidic and alkaline solutions. The value of $\mathrm{E}_{\mathrm{a}}$ for the alkaline leg is $154 \mathrm{~kJ} / \mathrm{mol}$ and the value of $\mathrm{E}_{\mathrm{a}}$ for the acid leg is $99.0 \mathrm{~kJ} / \mathrm{mol}$. These are much higher than the values used in the HLW glass degradation model, which are 69 and $31 \mathrm{~kJ} / \mathrm{mol}$ for the alkaline and acidic legs, respectively. The activation energies determined from the rates measured for the LaBS glass at $90^{\circ} \mathrm{C}$ and the Loeffler glass at $70^{\circ} \mathrm{C}$ are unreasonably high. This is attributed to differences in the test apparatus and procedures used at PNNL and LLNL as well as the difference in composition of the LaBS and Loeffler glasses.

The values of $\eta$ and $E_{a}$ that were measured in tests with various borosilicate glasses are summarized in Table 8 (Table 7.4-1 from BSC 2003a). Although differences in the values measured for different glasses are fairly large, the values of $E_{a}$ determined for these glasses are all much lower than those calculated for LaBS glass for both acidic and alkaline solutions. Confirmation that the temperature dependence used in the HLW glass degradation model is representative of LaBS glass degradation requires that the temperature dependence be measured for the LaBS glass. If it is found that the activation energy for LaBS glass is indeed much higher for HLW glass, the HLW glass degradation model will likely be a bounding model. If comparison of test results at $90^{\circ} \mathrm{C}$ indicates the model bounds LaBS glass degradation, then extrapolation to lower temperatures using a high activation energy will result in a lower rate than extrapolation using a low activation energy. However, the high activation energies determined by comparison of the LaBS and Loeffler glasses are not sufficiently reliable to conclude the model is bounding.

Table 8. Values of $\eta$ and $E_{a}$ Measured for Different Glasses

\begin{tabular}{|c|c|c|c|c|}
\hline Glass & $\eta$ & $\mathbf{E}_{\mathrm{a}}, \mathrm{kJ} / \mathrm{mol}$ & H & $\mathrm{E}_{\mathrm{a}}, \mathrm{kJ} / \mathrm{mol}$ \\
\hline & \multicolumn{2}{|c|}{ Acidic Solutions } & \multicolumn{2}{|c|}{ Alkaline Solutions } \\
\hline SRL 202G & -0.49 & 31 & 0.49 & 69 \\
\hline $\mathrm{CSG}$ & -0.70 & 60 & 0.49 & 85 \\
\hline MW & -0.43 & 32 & 0.43 & 56 \\
\hline LD6-5412 & -- & -- & 0.40 & 75 \\
\hline R7T7 & -- & -- & 0.39 & 59 \\
\hline Binder Glass & -0.36 & 72 & 0.64 & 83 \\
\hline
\end{tabular}


PCT Method A Response: In the HLW glass degradation model, the extent of dissolution that occurs in a 7-day PCT is used to calculate an upper limit for the long-term corrosion rate. The rationale is that the solution chemistry generated during the first 7 days of reaction is representative of the solution chemistry after long corrosion times. Although the test conditions of reacting a small amount of crushed glass in a relatively large volume of water is not obviously representative of a glass log contacted by a thin film of water in a breeched waste package, the solution chemistries generated in the test and in the waste package are surprisingly similar. This can be understood by the similarity in the $\mathrm{S} / \mathrm{V}$ ratios: an $\mathrm{S} / \mathrm{V}$ ratio of $2000 \mathrm{~m}^{-1}$ is equivalent to a film of water $0.5 \mathrm{~mm}$ thick on a planar glass surface. This is a reasonable estimate of the amount of water that could accumulate by condensation of water vapor on a waste glass after a brine is generated. (The in-package chemistry model requires much thicker water films, e.g., $0.2 \mathrm{~cm}$, to simulate the chemistry during corrosion of the waste and container materials using geochemical computer models.) Using crushed glass in the PCT allows sufficient solution to be used in the test to allow post-test analysis. The glass dissolution rate will generally decrease with time as the solution becomes more concentrated in glass components (particularly silica). The dissolution rate may increase if phases that consume silica precipitate. The 7-day rate provides an upper limit for the long-term rate even after such phases form.

The feedback effect of dissolved silica on the dissolution rate of the LaBS glass can be seen by comparing the rate measured in 7-day PCTs to the rate measured in SPFT tests, both at $90^{\circ} \mathrm{C}$. The rate measured in 7-day PCTs was $0.0098 \mathrm{~g} /\left(\mathrm{m}^{2} \mathrm{~d}\right.$ ) and the final $\mathrm{pH}$ was 8.1 (at room temperature). A solution with $\mathrm{pH} 8.1$ at room temperature is expected to have a $\mathrm{pH}$ of about 8.9 at $90^{\circ} \mathrm{C}$. From the line fit to the SPFT test results in alkaline solutions in the plot in Fig. 1, the rate at $\mathrm{pH} 8.9$ is: $\log$ rate $=-3.99+0.437 *(8.9)=-0.1007$, and the corresponding rate $=0.79$ $\mathrm{g} /\left(\mathrm{m}^{2} \mathrm{~d}\right)$. This indicates that the rate is reduced by about $80 \mathrm{X}$ due to the buildup of dissolved glass components (primarily silica) in the PCT solution. Further dissolution of the LaBS glass is expected to result in still lower rates.

Long-term Degradation: Although few tests have been conducted to study the long-term degradation behavior of the LaBS glass, insight is provided by the PCT conducted at $20,000 \mathrm{~m}^{-1}$ and by the VHTs. The dissolution rate of borosilicate glasses is known to decrease as the concentration of dissolved silica increases. This is represented by the chemical affinity term (1$\mathrm{Q} / \mathrm{K}$ ) in the mechanistic rate expression (see Eq. 1). As the concentration of dissolved silica (Q) approaches the apparent saturation concentration $(\mathrm{K})$, the chemical affinity becomes very small. The dissolution rates of some glasses have been observed in laboratory experiments to increase coincidentally with the formation of alteration phases, usually zeolite phases. It has been hypothesized that the increase in the rate is due to the consumption of dissolved silica as the alteration phases precipitate, and that the alteration phases establish a lower solubility limit for dissolved silica than the glass. This establishes a higher value of the affinity term than was attained prior to the formation of those phases.

The time required to observe solution feedback effects can be shortened by reducing the volume of solution the glass components are released into and by increasing the glass dissolution rate. PCTs can be conducted at higher S/V ratios to increase the rate at which the solution becomes concentrated. The temperature of the PCT is usually not increased above $90^{\circ} \mathrm{C}$, although this would provide an additional means of accelerating the reaction progress. The results of tests conducted with LaBS glass at $20,000 \mathrm{~m}^{-1}$ for 28,98 , and 182 days were presented in Table 4 . The normalized concentrations of $\mathrm{B}, \mathrm{Si}, \mathrm{Pu}$, and $\mathrm{Gd}$ are plotted against the product of the $\mathrm{S} / \mathrm{V}$ 
ratio and the test duration in Figure 5a. (The normalized concentrations were calculated by multiplying the normalized mass losses by the $\mathrm{S} / \mathrm{V}$ ratios and dividing by 1000 to convert $\mathrm{g} / \mathrm{m}^{3}$ to $\mathrm{g} / \mathrm{L}$.) The release of both $\mathrm{B}$ and $\mathrm{Si}$ is highest after 98 days $(\mathrm{S} / \mathrm{V} \bullet \mathrm{t}=2 \mathrm{E} 6 \mathrm{~d} / \mathrm{m})$. The lower values of $\mathrm{NC}(\mathrm{B})$ and $\mathrm{NC}(\mathrm{Si})$ after 182 days may indicate the limit of the test method to measure the dissolution rate. Regardless, it is clear that little additional glass is expected to dissolve beyond 98 days under these test conditions. Note that the maximum solution concentrations of $\mathrm{B}$ and $\mathrm{Si}$ are only about 10 times the concentrations measured in the 7-day tests. Note also that division of the measured concentration by the mass fractions of $\mathrm{B}$ and $\mathrm{Si}$ in the LaBS glass results in values of NL(B) being higher than the values of $\mathrm{NL}(\mathrm{Si})$, even though all the solutions have higher concentrations of silicon. The releases of $\mathrm{Pu}$ and $\mathrm{Gd}$ are similar and both are bounded by the releases of $\mathrm{Si}$ and $\mathrm{B}$.

The values of $\mathrm{NC}(\mathrm{B})$ measured for LaBS glass are compared in Fig. 5b with corresponding values from previous tests conducted under the same conditions with reference DWPF glasses made with frits SRL 131 and SRL 202 (Ebert 1994). The glass made with SRL 131 frit was formulated to represent Purex glass and the glass made with SRL 202 frit was formulated to represent the design basis glass. These glasses are near the extremes in the composition of possible HLW glasses used to encapsulate the LaBS glass in the can-in-canister design. Based on the release of boron, the LaBS glass is more durable than either of the reference HLW glasses. This comparison indicates that the HLW glass encapsulating the LaBS glass will dissolve faster than the LaBS glass itself. This will ensure that the encapsulating glass will dominate the solution chemistry within a breeched waste package. This will impact the dissolution rate of the LaBS glass through the $\mathrm{pH}$ and affinity term.

Vapor hydration tests are used to promote the formation of alteration phases and study the impact on the glass degradation rate. The VHT can be used to identify glass compositions that are likely to be affected by the formation of alteration phases after long corrosion times. The same phases are generally formed in VHTs and in long-term PCTs, although some differences may occur due to the difference in test temperature. The VHTs are usually conducted at temperatures between 150 and $200^{\circ} \mathrm{C}$, whereas the PCTs are usually conducted at $90^{\circ} \mathrm{C}$. The higher temperatures used in the VHTs accelerate glass dissolution and the attainment of highly concentrated solutions, which promotes the formation of alteration phases. Based on the amount of water available to condense on the sample, the $\mathrm{S} / \mathrm{V}$ ratio in a VHT is about $8000 \mathrm{~m}^{-1}$. The VHTs conducted with LaBS glass revealed formation of a clay-like aluminosilicate material and a plutonium silicate phase. No zeolite phases were detected - zeolites are not expected to form due to the absence of alkali metals. In the absence of zeolites, rate-affecting alteration phases are not expected to form due to degradation of LaBS glass. Clays are commonly formed during the corrosion of borosilicate waste glasses and have been found not to affect the dissolution rate. However, degradation of the HLW glass that encapsulates the LaBS glass may result in the formation of silica-consuming alteration phases that could increase the dissolution rate of the LaBS glass. The HLW glass degradation model implicitly assumes that all glasses will be affected by alteration phase formation, and the maximum rate calculated by the model was selected to provide an upper bound to the rates measured after alteration phases formed in longterm PCTs. 


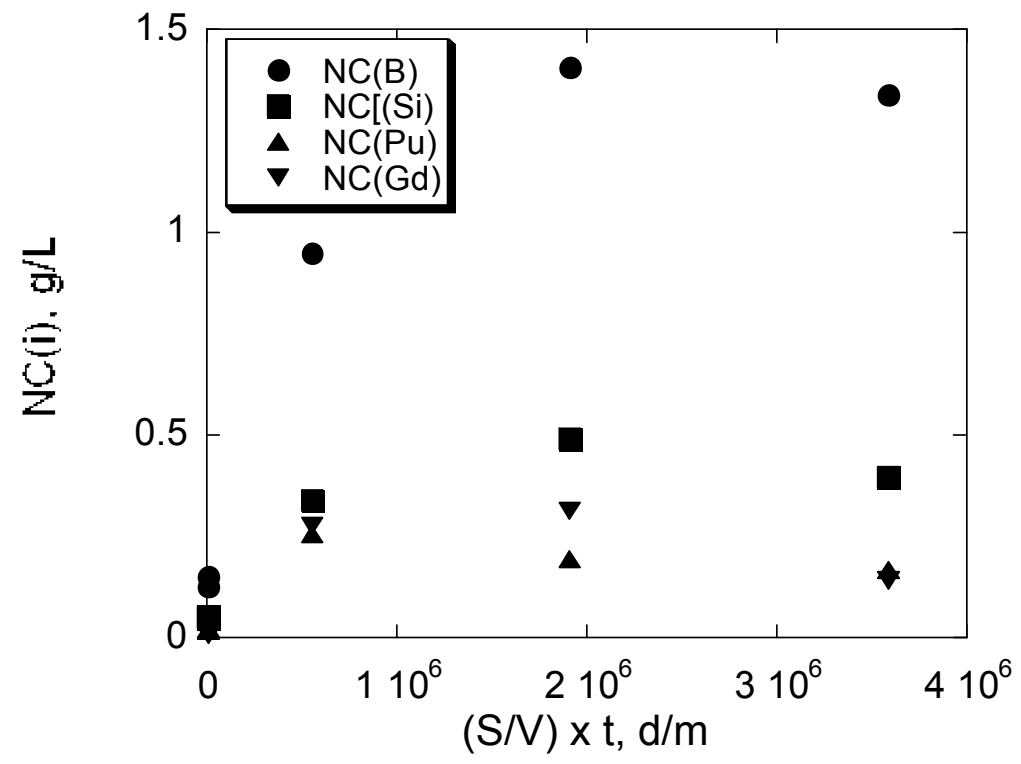

(a)

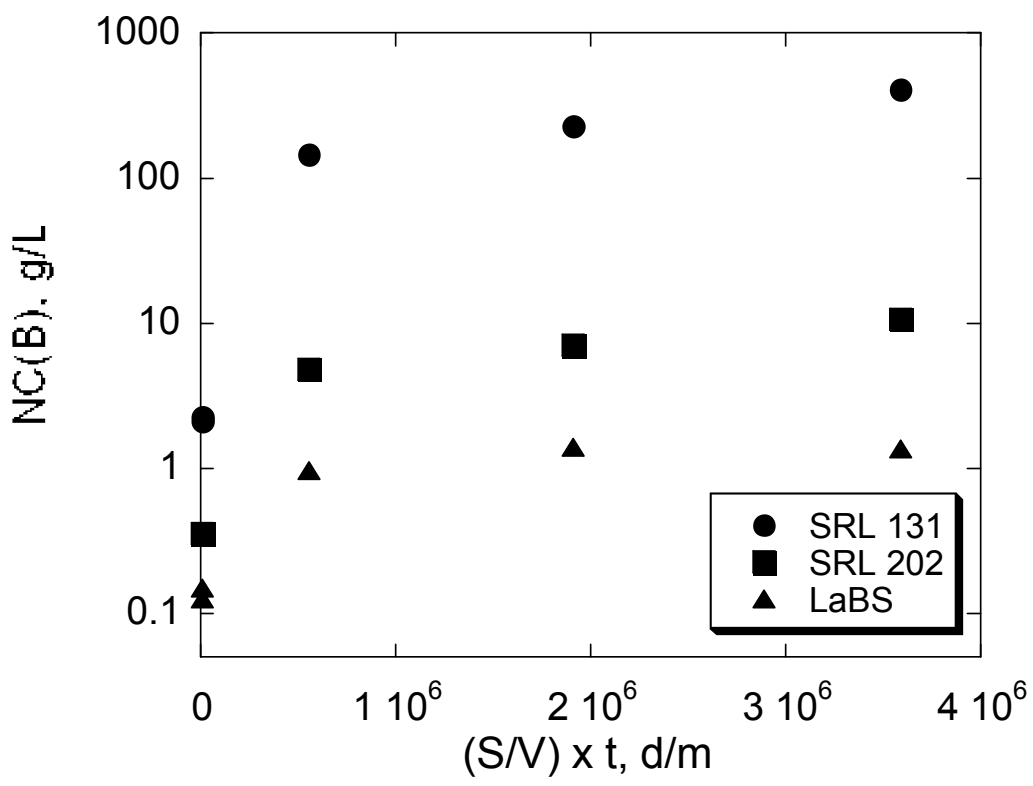

(b)

Figure 5. Normalized Concentrations of (a) B, Si, Pu, and Gd in PCTs with LaBS Glass and (b) B in PCTs with LaBS, SRL 131, and SRL 202 Glasses.

The results of VHTs with LaBS glass provides insight into two other issues: the solubility limit for plutonium and the formation of Pu-bearing colloids. These issues are discussed in Sections 7.0 and 8.0, respectively. 
Comparison with Rate Expression for Glass Degradation: The results of the 7-day PCTs with LaBS glass can be used to determine if the maximum degradation rate provided by the Defense HLW Glass Degradation Model provides an upper bound to the degradation rate of the LaBS glass. As illustrated in Fig. 3, the results of 7-day PCTs with a range of reference borosilicate waste glasses were used to establish the maximum value for $\mathrm{k}_{\mathrm{E}}$ in alkaline solutions. This was done by solving Equation 2 for $\mathrm{k}_{\mathrm{E}}$ by using rate $_{G}=\mathrm{NR}(\mathrm{B}), \eta=0.49$, and $\mathrm{E}_{\mathrm{a}}=69 \mathrm{~kJ} / \mathrm{mol}$, and using the $\mathrm{pH}$ measured at room temperature and $\mathrm{T}=363 \mathrm{~K}$. Whether or not the modeled rate bounds the rate of the LaBS glass can be determined by comparing the rate calculated using the maximum value of $\mathrm{k}_{\mathrm{E}}$ and the $\mathrm{pH}$ measured in the 7-day PCT with the LaBS glass in Eq. 2 with the rate measured in the PCT with the LaBS glass. From the average of the results for the two 7day PCTs given in Table 2, the $\mathrm{pH}$ at room temperature is 8.1 and $\mathrm{NL}(\mathrm{B})$ is $0.69 \mathrm{~g} / \mathrm{m}^{2}$. The maximum rate from the model at $\mathrm{pH} 8.1$ is:

$$
\text { rate }_{G}=3.47 \times 10^{4} \cdot 10^{0.49 . \mathrm{pH}} \cdot \exp [-69 /(0.008314 \cdot 363 \mathrm{~K})]=0.038 \mathrm{~g} /\left(\mathrm{m}^{2} \bullet \mathrm{d}\right)
$$

The average rate in the 7-day PCT is simply $0.69 \mathrm{~g} / \mathrm{m}^{2}$ divided by 7 days $=0.010 \mathrm{~g} /\left(\mathrm{m}^{2} \bullet \mathrm{d}\right)$. Thus, the rate calculated with the Defense HLW Glass Degradation Model provides an upper bound to the rate measured in the PCT. 


\subsection{RADIONUCLIDE INVENTORY}

\subsection{Basis for Estimates}

The actinide content that would be expected in the waste packages containing can-in-canister assemblies for disposal in the Federal Radioactive Waste Repository was projected. A configuration of five canisters containing immobilized plutonium (i.e., five can-in-canister assemblies) per waste package was utilized for these calculations. It should be noted that this configuration was one that was previous analyzed and reported in an Inventory Analysis and Modeling Report (BSC 2000).

The previous evaluations supporting the Office of Civilian Radioactive Waste Management during PIP were based on a 17 MT total throughput in the immobilization plant (B0000000001717-4301-00006 REV 01 and BSC 2000). With feed streams that will be dispositioned by alternate methods, including MOX and direct disposal to waste, the expected quantity of material requiring immobilization is now reduced to between $7 \mathrm{MT}$ and $13 \mathrm{MT}$. Therefore, two scenarios were considered to bound the amount of plutonium that is currently candidate for disposition via LaBS glass and the can-in-canister technology. Specifically, the cases considered included plutonium inventories representing the 7 MT case and 13 MT cases. The estimate for the 7 MT case was based on immobilizing plutonium that was surplus to U.S. programmatic needs; that would not be disposed as spent fuel, transuranic, or low-level or mixed waste; and that would not be suitable for disposition via the Mixed Oxide (MOX) fuel cycle proposed for operation by the DOE Office of Fissile Materials Disposition (DOE-MD). The 13 MT case included the material specified in the $7 \mathrm{MT}$ case as well as the material that at this time is considered to be acceptable for the MOX fuel cycle. Flowsheets for the MOX process are under development. No surplus non-pit plutonium materials have been officially "accepted" for treatment in the MOX Fuel Fabrication Facility (MFFF) or Pit Disassembly and Conversion Facility (PDCF). Therefore, the 13 MT case represented an upper bound case in the event that no candidate plutonium material is acceptable for the MOX fuel cycle.

\subsection{Radionuclide Inventory}

Table 9 summarizes a preliminary radionuclide composition for the primary actinide materials stabilized in the LaBS glass for both the 7 MT and 13 MT cases. It does not include contributions from DWPF high-level waste glass that would be used to encapsulate the cans of LaBS glass and serve as a radiation barrier. However, the contribution of HLW glass could be readily added using radionuclide projections of the HLW waste glass for the timeframe of canin-canister production. Additionally, it does not include the minor radionuclides resulting from radioactive decay. These radionuclides could also be easily obtained using existing radioactive decay methodologies. It was assumed that a waste package would consist of five DWPF canisters, each of which contained $16 \mathrm{~kg}$ of actinides within the inner cans that contain the disposition form. 
Table 9. Preliminary Actinide Contents for 7 MT and 13 MT cases

\begin{tabular}{|l|r|r|r|r|r|}
\hline & & \multicolumn{2}{|c|}{7 MT Case } & \multicolumn{2}{c|}{ 13 MT Case } \\
\hline Isotope & $\begin{array}{c}\text { Specific Ac- } \\
\text { tivity, Ci/g }\end{array}$ & $\begin{array}{c}\text { grams per } \\
\text { package }\end{array}$ & $\begin{array}{c}\text { Ci per } \\
\text { package }\end{array}$ & $\begin{array}{c}\text { grams per } \\
\text { package }\end{array}$ & $\begin{array}{c}\text { Ci per } \\
\text { package }\end{array}$ \\
\hline & & & & & \\
\hline $\mathrm{Am}-241$ & $3.428 \mathrm{E}+00$ & 1034 & $3.54 \mathrm{E}+03$ & 584 & $2.03 \mathrm{E}+03$ \\
\hline $\mathrm{Np}-237$ & $7.045 \mathrm{E}-04$ & 20 & $1.42 \mathrm{E}-02$ & 10 & $7.19 \mathrm{E}-03$ \\
\hline $\mathrm{Pu}-238$ & $1.713 \mathrm{E}+01$ & 144 & $2.47 \mathrm{E}+03$ & 72 & $1.23 \mathrm{E}+03$ \\
\hline $\mathrm{Pu}-239$ & $6.207 \mathrm{E}-02$ & 70,600 & $4.38 \mathrm{E}+03$ & 73,008 & $4.53 \mathrm{E}+03$ \\
\hline $\mathrm{Pu}-240$ & $2.271 \mathrm{E}-01$ & 8584 & $1.95 \mathrm{E}+03$ & 6528 & $1.48 \mathrm{E}+03$ \\
\hline $\mathrm{Pu}-241$ & $1.030 \mathrm{E}+02$ & 416 & $4.28 \mathrm{E}+04$ & 264 & $2.72 \mathrm{E}+04$ \\
\hline $\mathrm{Pu}-242$ & $3.938 \mathrm{E}-03$ & 256 & $1.01 \mathrm{E}+00$ & 128 & $5.04 \mathrm{E}-01$ \\
\hline Th-232 & $1.101 \mathrm{E}-07$ & 708 & $7.78 \mathrm{E}-05$ & 328 & $3.61 \mathrm{E}-05$ \\
\hline $\mathrm{U}-234$ & $6.214 \mathrm{E}-03$ & 185 & $1.15 \mathrm{E}+00$ & 89 & $5.55 \mathrm{E}-01$ \\
\hline $\mathrm{U}-235$ & $2.161 \mathrm{E}-06$ & 11,289 & $2.44 \mathrm{E}-02$ & 5496 & $1.19 \mathrm{E}-02$ \\
\hline $\mathrm{U}-238$ & $3.360 \mathrm{E}-07$ & 38,764 & $1.30 \mathrm{E}-02$ & 18,024 & $6.06 \mathrm{E}-03$ \\
\hline & & & & & \\
\hline Totals Ci & & & $5.51 \mathrm{E}+04$ & & $3.65 \mathrm{E}+04$ \\
\hline Total Pu & & 80,000 & & 80,000 & \\
\hline
\end{tabular}

Note: Pu-241 and Am-241 percentages were decayed to October 1, 2003 for these calculations.

There are some notable differences between the $7 \mathrm{MT}$ and $13 \mathrm{MT}$ projections. For the $7 \mathrm{MT}$ case most of the weapons-grade plutonium would be dispositioned via the MOX fuel cycle. Therefore, for the $7 \mathrm{MT}$ case, the assay of Pu-239 is lower and the assay of Am-241, Pu-238, Pu$240, \mathrm{Pu}-241$, and $\mathrm{Pu}-242$ is higher for an average waste package. The net result is a significant increase in the Curie content per waste package for the $7 \mathrm{MT}$ case. This is primarily attributable to the increase in Am-241, Pu-238 and Pu-241 in the waste package. 


\subsection{COMPARISON TO TSPA MODELS}

Section 4 discussed the HLW degradation process model and how LaBS glass fits within the bounds of that model. In this section, the relevance of other existing process models used for TSPA to LaBS glass is summarized from the perspectives of (1) is the way the model treats HLW glass appropriate for treating LaBS glass and (2) will including HLW glass with embedded LaBS glass in the waste inventory impact the way HLW glass is modeled.

\subsection{Initial Radionuclide Inventory Model}

Consistency of the Behavior of LaBS Glass with How Model Treats HLW Glass: The Initial Radionuclide Inventory Model (BSC 2003d) provides the inventories of important radionuclides in commercial spent nuclear fuel (CSNF), DOE-managed spent nuclear fuel (DSNF), and HLW glass. In TSPA calculations, the glass degradation rate provided by the Defense HLW Glass Degradation Model will be coupled with the HLW glass inventory to calculate the amounts of radionuclides released as the glass degrades. The Initial Radionuclide Inventory Model provides a weighted average radionuclide content of waste packages containing HLW glass based on the number of glass logs and inventories from each HLW glass producing facility. This is provided in terms of nominal grams per waste package. A nominal mass (curie content) is used for every waste package containing HLW glass, even though the amounts of HLW glass will vary significantly among different package configurations, as summarized in Table 10. The short HLW glass canisters will include HLW glass from DWPF and WVDP. The long HLW glass canisters will include HLW glass from Hanford.

Table 10. Waste Package Configurations

\begin{tabular}{|c|c|l|}
\hline $\begin{array}{c}\text { Configuration } \\
\text { Number }\end{array}$ & $\begin{array}{c}\text { Number of } \\
\text { Packages }\end{array}$ & \multicolumn{1}{c|}{ Description } \\
\hline 6 & 1147 & 1 short DSNF and 5 short HLW glass canisters \\
\hline 7 & 1406 & 1 long DSNF and 5 long HLW glass canisters \\
\hline 8 & 31 & 1 short DSNF and 5 long HLW glass canisters \\
\hline 9 & 679 & 5 long HLW glass canisters \\
\hline 10 & 149 & 2 multi-canister overpacks and 2 long HLW glass canisters \\
\hline
\end{tabular}

Impact of Including LaBS Glass on Model: The current Initial Radionuclide Inventory Model includes 679 waste packages containing only HLW glass and 2733 waste packages with HLW glass and DSNF; it does not include any packages with HLW glass plus embedded LaBS glass. Knowledge of the radionuclide inventory for HLW glass with embedded LaBS glass will allow the average inventory for HLW glass to be revised.

\subsection{In-Package Chemistry Assessment}

Consistency of the Behavior of LaBS Glass with How Model Treats HLW Glass: The In-Package Chemistry Model provides the values of $\mathrm{pH}$, Eh, ionic strength and concentrations of carbonate and fluoride in the water that accumulates in a breeched waste package for use in other models (BSC 2003b). Values of these variables are calculated by coupling the corrosion rates of metallic components of the waste package, the degradation rates of HLW glass and spent fuels, and estimated compositions and volumes of water and tracking the evolution of the solution chemistry over time. Values are provided for two limiting volumes of water: condensed water vapor generates a $0.2-\mathrm{cm}$-thick film of water and seepage water generates a 0.35 -cm-thick film in waste packages containing HLW glass. The HLW glass degradation rate model only uses the $\mathrm{pH}$ from the In-Package Chemistry Value. (The other values are used to calculate the degradation 
rates of spent fuel and fuel cladding failure.) Simulations for waste packages with HLW glass give a range of $\mathrm{pH}$ values from about 4 to 9 . When uncertainties are considered, the possible range of $\mathrm{pH}$ values provided by the current version of the In-Package Chemistry Model expands to about 2 to 11 for the range of temperatures, water volumes, and water flux.

The HLW glass model is valid over a range of $\mathrm{pH}$ values from about 1 to 12 (room temperature). The In-Package Chemistry Model does not indicate whether the $\mathrm{pH}$ is provided at-temperature or at room temperature. The HLW glass degradation model uses the $\mathrm{pH}$ at room temperature to calculate the rates at all temperatures. (This is because the test data used to develop the model provided the $\mathrm{pH}$ at room temperature.) Metal corrosion generally drives the solution $\mathrm{pH}$ to acidic values whereas HLW glass corrosion drives the solution $\mathrm{pH}$ alkaline. Simulations within the In-Package Chemistry Model show that the $\mathrm{pH}$ of condensed vapor increases over time due to predominance of glass degradation, whereas the $\mathrm{pH}$ of seepage water decreases with time due to the predominance of metal corrosion. The dissolution behavior of LaBS glass in the highly alkaline solutions that will be generated by HLW glass dissolution is understood (see Figure 1) and is bounded by the dissolution rate model. Based on the available data, the dissolution behavior of LaBS glass in acidic solutions is consistent with the HLW glass model.

Impact of Including LaBS Glass on Model: The In-Package Chemistry Model uses the degradation rate equation developed in the Defense HLW Glass Degradation Model to calculate the impact of glass degradation on the solution chemistry. The primary impact of glass dissolution is on the alkalinity of the solutions and the $\mathrm{pH}$. The MCC-1 static leach tests and PCTs discussed in this report indicate that degradation of the LaBS glass does not have the same effect on $\mathrm{pH}$ as HLW glass degradation. For example, 7-day PCTs with the LaBS glass attain $\mathrm{pH}$ 8, whereas 7-day PCT with HLW glasses typically attain $\mathrm{pH} 10-11$. The effect of LaBS glass dissolution on the solution chemistry will be overwhelmed by the effect of the HLW glass in which the LaBS glass is embedded. The addition of cans of LaBS glass to the HLW glass will have a negligible influence on the alkalinity because of the small volume of LaBS glass relative to the HLW glass (LaBS glass represents only about $10 \%$ of the can-in-canister volume) and the absence of alkali metals in the LaBS glass.

\subsection{Dissolved Concentration Limits of Radioactive Elements} Consistency of the Behavior of LaBS Glass with How Model Treats HLW Glass: The solubility limit of plutonium used in TSPA calculations is provided by the Dissolved Concentration Limits of Radioactive Elements Model (BSC 2003e). That model uses a "blended plutonium solubility model" that is an average of the solubilities measured for crystalline $\mathrm{PuO}_{2}$ and partially amorphous $\mathrm{PuO}_{2}$ as the controlling solids. The solubility has a broad " $\mathrm{U}$ " shape $\mathrm{pH}$ dependence that is a function of the partial pressure of carbon dioxide. It is reasonable to assume that $\mathrm{PuO}_{2}$ will also control the solubility of plutonium released as LaBS glass degrades. The VHTs showed that a plutonium silicate was the initial Pu-bearing phase to form. The kinetically favored $\mathrm{PuSiO}_{4}$ phase is expected to have a higher solubility than the thermodynamically favored $\mathrm{PuO}_{2}$ phase. However, it is likely that degradation of the HLW glass embedding the LaBS glass will establish $\mathrm{PuO}_{2}$ as the solubility controlling phase long before the LaBS glass degrades.

Tests with Pu-bearing LaBS glass indicate that $\mathrm{Pu}$ and $\mathrm{Gd}$ are released to solution about $10 \mathrm{X}$ slower than B and 2.5X slower than Si under PCT conditions. These results are based on analysis of test solutions only after coarse filtration to ensure no particles of LaBS glass were carried over into the analyzed solution. Although the release of B is used to calculate the glass degradation rate and radionuclide release rate in the HLW glass degradation model, the release 
of Si provides the best measure of the glass matrix degradation rate and solubility control in those tests.

Impact of Including LaBS Glass on Model: The concentration limits of radionuclides are based on the solubility controlling phases, which are independent of the waste forms. Including HLW glass logs with embedded LaBS glass will not affect the Dissolved Concentration Limits Model.

\subsection{Colloid-associated Radionuclide Concentrations} Consistency of the Behavior of LaBS Glass with How Model Treats HLW Glass: The Waste Form and Indrift Colloids-Associated Radionuclide Concentrations Model (BSC 2003f) addresses the types and concentrations of colloids generated by degradation of waste forms and waste package materials, engineered barrier materials, and the natural environment. Colloids from degradation of HLW glass are modeled to be clay with embedded radionuclide-bearing phases. The radionuclides are modeled to be permanently fixed to the colloid. This is a key assumption in the model because filtration of the colloid will immobilize the associated radionuclides. (Detachable radionuclides could dissolve and continue to migrate.) The concentrations of radionuclides associated with colloids are related to the abundance and size of colloids measured in laboratory tests with DWPF reference glasses. The clay colloids are probably formed by spallation from the surface of corroded glass, as it is unlikely that clays would precipitate from the solution. Radionuclide-bearing crystallites within the clay are carried into solution as part of the colloidal clay. Dissolved radionuclides will sorb onto both clay fixed to the glass and clay colloids. As the solution chemistry evolves, colloids can aggregate and settle out of solution. The Colloid Model relates the concentration of plutonium associated with colloids to the ionic strength of the solution, and to the concentration of colloids. Separate analysis of the colloid concentration and the plutonium concentration in several PCT solutions indicates a correspondence of 1 ppm colloids with $2 \mathrm{E}-8 \underline{\mathrm{M}} \mathrm{Pu}$. The concentration of $\mathrm{Pu}$ associated with colloids is determined as a function of the ionic strength as summarized in Table 11. The ionic strength is provided by the In-Package Chemistry Model.

Table 11. Concentration of Plutonium in Colloids as Function of Ionic Strength

\begin{tabular}{|c|c|}
\hline Ionic Strength (I) & $\mathbf{C}_{\text {Pu,coll }}(\underline{\mathbf{M})}$ \\
\hline $\mathrm{I}<0.01 \underline{\mathrm{M}}$ & $1 \mathrm{E}-7$ \\
\hline $0.01 \underline{\mathrm{M}}<\mathrm{I}<0.05 \underline{\mathrm{M}}$ & $1.25 \mathrm{E}-7-2.5 \mathrm{E}-6 \times \mathrm{x}$ \\
\hline $\mathrm{I}>0.05 \underline{\mathrm{M}}$ & $1 \mathrm{E}-11$ \\
\hline
\end{tabular}

It must be emphasized that the decrease in the concentration of plutonium with ionic strength only reflects what is transportable as colloidal material. Flocculated colloids will settle from solution as the ionic strength increases, but can be resuspended if the solution chemistry changes.

The VHTs indicate that a clay similar to those formed during HLW glass degradation will form as the LaBS glass degrades. Spallation of the clay can transport plutonium into solution by the same mechanism as for HLW glass. LaBS glass can be treated the same as HLW glass in the Colloid Model. Limits on the stability of colloids generated by degradation of LaBS glass in solution is expected to be the same as the stability of colloids from HLW glasses, and the same functionality between the stability of colloids and the ionic strength of the solution should be appropriate. 
Impact of Including LaBS Glass on Model: The treatment of HLW glass in the Colloid Model is based directly on test results with HLW glass. The plutonium content of the glasses used in those tests probably affects the amount of plutonium in the colloids and, ultimately, the relationship between the plutonium concentration in the colloidal fraction and the ionic strength. The correlation of $1 \mathrm{ppm}$ colloids with $2 \mathrm{E}-8 \underline{\mathrm{M}} \mathrm{Pu}$ is similar to the $\mathrm{Pu}$ content in the glass, which is on the order of 0.1 mass $\%$ for HLW glasses. Because the concentration of plutonium is much higher in the LaBS glass than in HLW glasses (about 100X), the concentrations $\mathrm{C}_{\mathrm{Pu} \text {,coll }}$ in colloids generated by LaBS glass are expected to be proportionally much higher than the concentrations in Table 10. The current Colloid Model is expected to underestimate the concentration of plutonium associated with colloids generated as LaBS glass degrades. The impact on the dose calculation will be diluted by the small amount of LaBS glass embedded in the HLW. In addition, colloids will be efficiently filtered by the host geology and are not currently expected to impact the dose calculations. 


\subsection{SUMMARY}

Available tests data for the LaBS glass formulated to immobilize surplus plutonium were evaluated and compared with models developed to calculate the release and disposition of radionuclides from HLW glasses disposed in the Yucca Mountain repository. The comparison focused on the adequacy of the Defense HLW Glass Degradation Model for calculating the LaBS glass degradation behavior. Key aspects of the comparison are the $\mathrm{pH}$ and temperature dependence of the glass dissolution rate, and the rates measured under particular water contact conditions. The $\mathrm{pH}$ dependence of LaBS glass dissolution in both acidic and alkaline solutions is consistent with that used in the model, although additional data is needed to confirm the agreement at low $\mathrm{pH}$ values. Data are also needed to confirm that the temperature dependence is adequately represented. The glass degradation behavior of the LaBS glass relevant to long corrosion times is consistent with HLW glasses, namely that the degradation rate slows as dissolved components accumulate in the solution. The rates calculated by the Defense HLW Glass Degradation Model bound the rates for LaBS glass in alkaline solutions. Data in hand suggest that the model does not bound LaBS glass dissolution in acidic solutions. However, since the dissolution rate for the HLW glass is higher than the LaBS glass, it is likely that due to dissolution of the HLW glass embedding the LaBS glass alkaline conditions will be maintained in a breeched waste package. The model developed to calculate the solution chemistry in breeched waste packages containing HLW glass is applicable to HLW glass with embedded LaBS glass.

The fractionation of plutonium released from LaBS glass between dissolved, sorbed, and colloidal fractions is expected to be the same as for HLW glasses, although data are not available to confirm this. Insight from long-term and accelerated tests suggests most of the released plutonium will be associated with clay colloids and the solubility will be controlled by $\mathrm{PuO}_{2}$. Models developed to calculate the amounts of radionuclides released from HLW glass that become associated with colloids or dissolved are applicable to radionuclides released from LaBS glass.

The models developed for TSPA calculations will adequately represent the impacts of LaBS glass degradation on repository performance. Models for HLW glass degradation, in-package chemistry, colloid-associated radionuclides, and solubility limits can be applied without modification. Revision of the HLW glass radionuclide inventory will be required because the increases in the amounts of several plutonium isotopes will exceed the range of concentrations considered in the current model. This is a simple matter of recalculating the average concentrations in waste packages that include HLW glass. 


\subsection{RECOMMENDATIONS FOR FUTURE WORK}

It is recommended that some additional validation data on LaBS glass performance be obtained to augment the database since previous testing was not specifically aimed at evaluating repository performance. An overview of recommended testing follows.

Verify LaBS glass dissolution rate in acidic solutions: Additional tests should be conducted at $90^{\circ} \mathrm{C}$ in acidic solutions to verify $\mathrm{pH}$-dependence between $\mathrm{pH} 1$ and $\mathrm{pH}$ 6. This is needed to provide additional data in the $\mathrm{pH}$ range determined from the Yucca Mountain Project in-package chemistry model.

Measure temperature dependence: No reliable data are available to demonstrate that the temperature dependence in the Defense HLW Glass Degradation Model is appropriate for the LaBS glass. Comparison of tests with the LaBS glass and the compositionally similar Loeffler glass resulted in unreliably high effective activation energies in both acidic and alkaline solutions. Shortterm MCC-1 static leach tests can be conducted and combined with existing SPFT data to determine the temperature dependence. These tests are easier and more economical to conduct than SPFT tests. (Short-term MCC-1 static leach tests were used to measure the $\mathrm{pH}$ and temperature dependence for the HLW glass degradation model.) Tests should be conducted at a minimum of 3 acidic and 3 alkaline $\mathrm{pH}$ values. Series of 5 tests should be conducted for different durations between 2 and 12 days for each combination of temperature and $\mathrm{pH}$.

Verify scaling of PCT response by glass density: The density of the LaBS glass is about 1.6X higher than the densities of HLW glasses. The PCT Method A calls for tests to be conducted at a water/glass mass ratio of 10. Current waste acceptance requirement is that the response be less than that of the Environmental Assessment (EA) glass. Differences in glass densities will result in different surface areas available for reaction at a mass ratio of 10. The amount of LaBS glass used in the PCT must be increased to meaningfully compare with the response of HLW glasses and the EA glass. Tests should be conducted to demonstrate the scaling of the PCT response with the mass of LaBS glass used.

Verify Pu release behavior: Glass degradation results in the release of plutonium as dissolved and colloidal species. The amount of dissolved plutonium is controlled by solubility limits and the amount of suspended colloids is controlled by the ionic strength of the solution. Tests should be conducted to confirm that the models used in TSPA adequately account for the release behavior of plutonium from LaBS glass.

Verify Devitrification Behavior of LaBS glass: Previous testing implied that devitrification of the plutonium LaBS glass due to the exposure to the thermal cycle of the HLW glass pour would be unlikely. However, at that time the thermal profile of can-in-canister pouring operation was not known. Validation testing using the can-in-canister thermal profile followed by PCT Method A testing should be performed to confirm this behavior.

Verify No Impacts on Impurities: Previous testing showed that glass quality was not impacted by impurities associated with the plutonium in the $50 \mathrm{MT}$ and $17 \mathrm{MT}$ cases. The inventories of expected impurities with the 7 MT and 13 MT cases needs to be examined and, if necessary, bounding impurity glasses need to be prepared and evaluated using PCT Method A.

Analysis of Pressurized Unsaturated Flow (PUF) Test Results: The PUF test is designed to expose crushed glass to a combined stream of air and solution. A PUF test involving LaBS glass sandwiched between HLW glass layers recently completed after 7 years of exposure. The results of this testing should be examined to obtain dissolution data and alteration phase information. 


\subsection{ACKNOWLEDGEMENTS}

The authors wish to thank the significant and invaluable help of the following individuals in performing this work. Jeff Allender, George Becker, Ed Claxton, Scott Davies and Ranny Saylor are acknowledged for assistance in providing the radionuclide inventory data. Jim Cunnane and Bill Holtzscheiter are acknowledged for providing valuable guidance on the scope of this work. 


\subsection{REFERENCES}

Aagaard, P. and Helgeson, H.C. 1982. "Thermodynamics and Kinetic Constraints on Reaction Rates Among Minerals and Aqueous Solutions. I. Theoretical Considerations." American Journal of Science, 282, 237-285.

Bibler, N. E. et al. 1997. "Gamma and Electron Irradiation Studies of a Lanthanide Borosilicate Glass for Immobilizing Plutonium (U)," contained in Plutonium Immobilization: The Glass Option - A Compendium of Reports and Presentations, WSRC-RP-97-00902, Westinghouse Savannah River Company, Aiken, SC.

Ebert, W. 1994. The Effects of the Glass Surface Area/Solution Volume Ratio on Glass Corrosion: A Critical Review. Argonne National Laboratory report ANL-94/34.

Gould, T. 1998. Plutonium Immobilization Project, "Data forYucca Mountain Total Systems Performance Assessment," Letter report to Sarvajit S. Sareen, TRW Safety Systems, Inc., Vienna, VA, January 13, 1998, Lawrence Livermore National Laboratory, Livermore, CA, MOL.19980617.0472.

Grambow. B. 1985."A General Rate Equation for Nuclear Waste Glass Corrosion." Material Research Society Symposium Proceeding,_44, 15-24.

Li, H et al. 1998. "Component Solubility in Lanthanum Borosilicate Glasses for Vitrification of Plutonium Oxide and Plutonium Bearing Materials," Environmental and Waste Management Issues in the Ceramic and Nuclear Industries III, Ceramic Transactions, Vol. 87, American Ceramic Society, Westerville, $\mathrm{OH}$.

Marra, S. L. et al. 2001. "Qualification and Acceptance of the Immobilized Plutonium Waste Form", Environmental and Waste Management Issues in the Ceramic and Nuclear Industries VI, Ceramic Transactions, Vol. 119, American Ceramic Society, Westerville, OH.

Marshall, K. M. et al. 1998. "Development of a Melter System for Actinide Vitrification," Proceedings of the Third Topical Meeting on DOE Spent Nuclear Fuel and Fissile Materials Management, American Nuclear Society, Inc., LaGrange Park, IL.

Meaker, T. F. and Bibler, N. E. 1997a. "Characterization and Product Consistency Leach Tests of Lanthanide Borosilicate Glasses Containing Plutonium and Uranium or Impurities (U)," contained in Plutonium Immobilization: The Glass Option - A Compendium of Reports and Presentations, WSRC-RP-97-00902, Westinghouse Savannah River Company, Aiken, SC.

Meaker, T. F. and Bibler, N. E. 1997b. "Comparison of the Durabilities and Microstructures of an Amorphous and Devitrified Plutonium Bearing Lanthanide Borosilicate Glass (U)," contained in Plutonium Immobilization: The Glass Option - A Compendium of Reports and Presentations, WSRC-RP-97-00902, Westinghouse Savannah River Company, Aiken, SC. 
Meaker, T.F. and Peeler, D.K. 1997a. "Solubility of Independent Plutonium Bearing Feed Streams in a Hf-Based LaBS Frit," contained in Plutonium Immobilization: The Glass OptionA Compendium of Reports and Presentations, WSRC-RP-97-00902, Westinghouse Savannah River Company, Aiken, SC.

Meaker, T.F. and Peeler, D.K. 1997b. "Result of an Interlaboratory Study of Glass Formulation for the Immobilization of Excess Plutonium," Report SRT-PUM-97-0017, contained in Plutonium Immobilization: The Glass Option - A Compendium of Reports and Presentations, WSRC-RP-97-00902, Westinghouse Savannah River Company, Aiken, SC.

Meaker, T.F. and Peeler, D.K. 1997c. "A Partial Time-Temperature-Transformation Diagram for a Plutonium Loaded Lanthanide Borosilicate (LaBS) Glass,” Report SRT-PUM-97-0017, contained in Plutonium Immobilization: The Glass Option - A Compendium of Reports and Presentations, WSRC-RP-97-00902, Westinghouse Savannah River Company, Aiken, SC.

Mertz, C., et al. 1998. "Comparison of the Corrosion Behavior of Plutonium Glasses," Environmental and Waste Management Issues in the Ceramic and Nuclear Industries VI, Ceramic Transactions, Vol. 87, American Ceramic Society, Westerville, OH.

Smith, M. E. et al. 2000. "Phase 2 Can-in-Canister Cold Pour Tests for the Plutonium Immobilization Project (U)," WSRC-TR-2000-00408, Westinghouse Savannah River Company, Aiken, SC.

Strachan, D. M. et al. 1998. "The Characterization and Testing of Candidate Immobilization Forms for Disposal of Plutonium”, Waste Management'98 Proceedings, Tucson, AZ.

Vienna, J. D. et al. 1996. "Plutonium Dioxide Dissolution in Glass," PNNL-11346, UC-510, Pacific Northwest National Laboratory, Richland, WA.

BSC 2003a. Defense HLW Glass Degradation. Report ANL-EBS-MD-000016 Rev 01.

BSC 2003b. In-Package Chemistry Abstraction. Report ANL-EBS-MD-000037 Rev 02.

BSC 2003c. DSNF and Other Waste Form Degradation Abstraction Model. Report ANL-WISMD-000004 REV 01.

BSC 2003d. Initial Radionuclide Inventories. Report ANL-WIS-MD-000020 Rev.00.

BSC 2003e. Dissolved Concentration Limits of Radioactive Elements. ANL-WIS-MD-000010 Rev 02.

BSC 2003f. Waste Form and Indrift Colloids-Associated Radionuclide Concentrations: Abstraction and Summary. MDL-EBS-PA-000004 Rev 00.

BSC 2000. Inventory Abstraction. Report ANL-WIS-MD-000006 REV 00 ICN 01. 
USDOE EM-0093 1996. U.S. Department of Energy, Office of Environmental Management, "Waste Acceptance Product Specifications for Vitrified High-Level Waste Forms," USDOE Document EM-0093, Revision 2.

TRW Environmental Safety Systems Inc. Total System Performance Assessment - Viability Assessment (TSPA-VA) Analyses Technical Basis Document. Chapter 6. Waste Form Degradation, Radionuclide Mobilization, and Transport Through the Engineered Barrier System, B00000000-01717-4301-00006 REV 01, November 13, 1998. 